\title{
A Transformational Change Framework for Developing Ecologically Embedded Manufacturing
}

\author{
H. Trollman ${ }^{1}$ (1) · J. A. Colwill ${ }^{1}$ (I)
}

Received: 28 November 2019/ Accepted: 25 September 2020/Published online: 16 October 2020

(C) The Author(s) 2020

\begin{abstract}
Unless strategies are adopted to ensure materials remain in circulation within the economy, the manufacturing sector may be unable to support increasing demand from a growing global population. The purpose of this research is to present a framework for manufacturers to aid in the formulation of ecologically embedded strategy. The framework proposes five steps which integrate corporate, business, operations and sustainability strategy in a holistic manner with operations strategy informing business strategy. Qualitative comparative analysis is implemented to identify the causal characteristics of ecologically embedded products which are then used to select two cases for the application of process tracing (PT). Product case studies indicate a failure to communicate provenance, quality and lifecycle information to consumers, and hence, the slowing or closing of loops as part of a circular economy is not being effectively realised. PT confirms the feasibility of the framework for ecocentric strategy formulation in manufacturing. Manufacturers, policymakers and investors may use this framework to leverage the benefits of ecological embeddedness to enable continued growth and future-proofing.
\end{abstract}

Keywords Circular economy - Ecological embeddedness . Manufacturing $\cdot$ Strategy $\cdot$ Sustainability

H. Trollman

H.Trollman2@lboro.ac.uk

1 Wolfson School of Mechanical, Electrical and Manufacturing Engineering, Loughborough University, Loughborough, UK

\section{Introduction}

The aim of this research is to develop a framework for ecologically embedded strategy in terms of corporate, business and functional strategies in manufacturing. The objectives of this research were to analyse the deficiencies in current frameworks and identify the causal characteristics of ecologically embedded products. Successful implementation of the proposed framework will rely on organisational flexibility to specify the relationship between strategy and subsystems (Morabito et al. 2009).

The dominant Brundtland-based definitions of sustainability have struggled to stimulate more than incremental anthropocentric benefits. Ecocentric approaches to corporate, business, or marketing strategy, as opposed to incremental anthropocentric sustainability, are infrequently considered in the literature. An exceptional example is the plastic electronics industry in the United Kingdom (UK) which recommends that managers and policymakers support and encourage ecocentric rather than anthropocentric approaches to eco-innovations (Borland et al. 2019). However, business models have yet to fully engage with sustainability as they are found to exclude natural and social aspects of organisational environment and neglect interrelationships between economic and non-economic actors as well as intertemporal trade-offs (Biloslavo et al. 2018). Notwithstanding, there is recognition that moving towards a more ecocentric corporate social responsibility (CSR) is necessary to improve maturity levels of corporate sustainability worldviews (Landrum and Ohsowski 2018).

Increasing energy costs, detrimental pollution levels, depletion of natural resources, stricter regulations, pressure from stakeholders and population growth are forcing industry to consider sustainable manufacturing fundamentals which balance environmental, economic and social 
objectives (Elkington 1998; Anbarasan and Sushil 2018). To preserve the environment and improve the quality of human life, Garetti and Taisch (2011) propose that innovative technologies, sustainable business models and lifestyle changes will be necessary. The associated sustainability discourse centres on practical relevance with 'pragmatic' strategies such as interorganisational collaboration to solve environmental problems (Bae and Grant 2018) and corporate stewardship (Luxmore et al. 2018). At systems level, a potential outcome of overrating the speed and effectiveness of current sustainability efforts is an uninhabitable planet.

Over the next 50 years, usage and waste by the manufacturing sector are expected to increase tenfold (Rashid et al. 2013). Consequently, the manufacturing sector engagement in sustainable development should be proportional to its impacts. The sustainability of future manufacturing firms will depend on the sustainability of their environment (Florida 1996; Sarkis 2001). Thus, the economic value generated by firms at high social and environmental costs would undermine their existence in future. A potential outcome of inadequate environmental response by the manufacturing sector is premature extinction of industrial activity. Consequently, many industries seek strategy for the creation of blue oceans (Khanmohammadi et al. 2019).

The most widely accepted framework for sustainability in general, and sustainable manufacturing in particular (Seuring and Müller 2008; Adams and Frost 2008; Jain and Kibira 2010), is the triple-bottom-line (TBL) approach introduced by Elkington (1997). This framework positions sustainable manufacturing at the intersection of environmental stewardship, economic growth and social wellbeing.

The TBL framework has been adopted in strategy research (Placet et al. 2005; Baumgartner and Ebner 2010; Kashmanian et al. 2011; Danciu 2013). Conceptual frameworks based on the TBL approach may be summarised as:

- furthering sustainability by collaboration in the supply chain (Ageron et al. 2012; Gimenez et al. 2012; Zahraee et al. 2018),

- a lifecycle approach (Yuan et al. 2012), and

- stakeholder roles in sustainability transformation (de Brucker et al. 2013; Matos and Silvestre 2013; Elias 2019).

However, the TBL has not yielded sufficient environmental and social change to decelerate continuing detrimental trends in these areas.

There is limited examination of traditional business strategies and their compatibility with sustainability (Sarka and Bouvrain 2015). Managerial paradoxes exist towards flexibility (Shukla et al. 2019). A recent review of strategic tools and frameworks available to organisations failed to identify any which substantially engaged with actual strategy development (Grainger-Brown and Malekpour 2019). The TBL approach is neither ecocentric nor is it a tool for strategy development. The transition from an anthropocentric to an ecocentric perspective is configured in the circular economy (CE); however, there is no specific guidance for assessing CE implementation at the level of individual companies (Prieto-Sandoval et al. 2018). There is also no shared framework on the application of CE to operations (Murray et al. 2017) or on adapting business models to the CE paradigm (Urbinati et al. 2017).

Switching from an anthropocentric to an ecocentric perspective is the key to achieving real sustainability, where humans use nature as inspiration to solve societal and environmental needs (Cohen-Rosenthal 2000; Hofstra and Huisingh 2014). This change of paradigm that is configured in the circular economy is visible through ecoinnovations, which are the tangible results of the CE system. CE business strategies have two categories: closing loops and slowing resource loops (Bocken et al. 2016), but a recent review identified that only $39.82 \%$ of research papers could be categorised based on these proposed strategies, and only $16 \%$ explored two or more business models at the same time (Merli et al. 2018). Few researches investigate how CE principles may be captured into business practices (Lieder and Rashid 2016; Manninen et al. 2017). CE initiatives addressing consumers are considered critical for the CE transition; however, they are generally not present (Stewart and Niero 2018).

Studies that have taken an ecocentric approach to production outside of manufacturing include those examining ecological embeddedness. The focus of these studies has been on agricultural production, e.g. (Penker 2006; Morris and Kirwan 2011; Baritaux et al. 2016). Morris and Kirwan (2011) proposed a four-dimensional framework for the empirical investigation of ecological embeddedness - understanding, realising, utilising and negotiating. Negotiating is about consumer perceptions and patterns of response to ecological information. The other three dimensions focus upstream to producer perceptions of the link between their practices and the environment and how this link is used to promote their products. Because this framework captures critical ecocentric relationships, a deeper understanding of its characteristics may serve as a stepping stone towards ecologically embedded manufacturing. Investigating ecologically embedded manufacturing is supported by both literature and the need to accelerate meaningful progress towards stable human existence within planetary boundaries.

Consequently, the purpose of this research is to answer the research question: 'How can ecological embeddedness 
be extended to strategy formulation in manufacturing'? where the word 'strategy' represents manufacturer corporate, business and functional strategies. More specifically, the following subquestions need to be addressed:

(1) What is current knowledge with respect to ecologically embedded products and strategy?

(2) Why are existing frameworks inadequate for ecologically embedded manufacturing?

(3) What function should a framework for ecologically embedded manufacturing fulfil?

(4) What are the causal characteristics of ecologically embedded products?

(5) Is it possible to extend the existing agricultural embeddedness framework to manufacturing?

(6) What are the benefits of ecologically embedded manufacturing?

Hence, this research attempts to identify key steps towards ecocentric manufacturing whilst relating them to strategy formulation for practical implementation. Landrum and Ohsowski (2018) advocate an extension of ecological embeddedness to enable ecological sensemaking in our highly industrialised society and as a means to aid corporations in adopting strong sustainability worldviews.

The sampling units of this research are individual products in the context of sustainable, green and/or circular manufactured products sold in the UK from July to October 2019 which are compared and contrasted with ecologically embedded products available at UK farmers' markets in the same time period. The units of analysis are the manufacturers/producers of these products.

In order to answer the research questions, initially extant literature relevant to ecological embeddedness is reviewed to address the first and second subquestions regarding current knowledge and the inadequacy of existing frameworks. This leads to identification of the functions that a framework for ecologically embedded manufacturing should fulfil (subquestion 3). Next research methodology is presented which describes how the characteristics of ecologically embedded products will be identified (subquestion 4) leading to validation of the proposed framework (subquestion 5). This is followed by the identification of two cases of ecologically embedded manufacturing so that benefits of ecologically embedded manufacturing are described (subquestion 6). Finally, an overview of achievements and limitations in the extension of ecological embeddedness to strategy formulation in manufacturing is discussed with the conclusion suggesting directions for future research.

\section{Literature Review}

The literature review begins with a brief outline of the foundations of ecological embeddedness. Current knowledge related to ecologically embedded products and strategy is then presented. This leads to the identification of the shortcomings of existing frameworks in describing ecologically embedded manufacturing and the proposal of an extended framework which addresses these shortcomings.

\section{Ecological Embeddedness}

Embeddedness was first described by the economic anthropologist Polanyi (1944) to argue that if humans and the natural environment are treated as pure commodities, their destruction is assured. Landrum and Ohsowski (2018) argue that our highly industrialised society and economy have led to a lack of ecological connection and awareness (disembeddedness), which limits our ability to find better and more innovative responses to complex environmental problems (Whiteman and Cooper 2011).

Embeddedness is metatheoretical, and as such, is rarely empirically described or tested. Whiteman and Cooper (2000) introduced ecological embeddedness as the extent to which a manager is on the land and learns from the land in an experiential way. The associated dimensions of ecological embeddedness identified by Whiteman and Cooper (2000) are personal identification with the land, adherence to ecological beliefs (with ecological reciprocity, ecological respect and ecological caretaking as subdimensions), gathering ecological information and being physically located in the ecosystem. There are certain parallels in manufacturing with environmental stewardship (Hassan et al. 2016; Bennett et al. 2018; Mathevet et al. 2018) in this description of ecological embeddedness.

Ecological embeddedness implies that the natural environment of the resources of production must inform and make a difference to the operation and development of production, including that it is part of the purchasing decision (Morris and Kirwan 2011). Agricultural production has been the focus of studies of ecological embeddedness; the concept has yet to be considered in the context of manufacturing. Ecological embeddedness should not be confused with environmental embeddedness, which is a term proposed to encompass activities that go beyond the biological or ecological to include resource use (Morris and Kirwan 2011).

In the context of on-farm food production, Morris and Kirwan (2011) propose that ecological embeddedness involves ongoing ecological relations between economic actors and the underlying ecology of production influencing economic activity to benefit both. This is the 
overarching perspective that will be used for the definition of causal characteristics for ecological embeddedness.

\section{Ecologically Embedded Products}

Ecologically embedded products should be discernable through their ongoing ecological relations. Communication is fundamental to relationships with marketing at the core of customer-producer relations.

Previous research on farmers' markets has rarely examined the marketing approach of producers (FigueroaRodríguez et al. 2019). Ethnographic results indicate that it is rare for sustainability to be communicated explicitly during the sales exchange, and explicit messages about sustainability are primarily limited to pamphlets and signs (Garner 2018). However, concepts such as 'local', 'environmentally conscious', 'chemical free' and 'organic' are often communicated to consumers (Garner 2018).

Marketing has relevant capability for fostering both sustainable consumption and cleaner production (Dangelico and Vocalelli 2017). Similar to the research on products at farmers markets, marketing strategy applicable to manufactured products often neglects the issue of sustainability (Kumar et al. 2013). Good green marketing strategy is based on two concepts for its definition: green marketing and greenwashing (Dangelico and Vocalelli 2017). Green marketing is defined as 'environmental sustainability as the third aim beyond consumers' satisfaction and company profitability' indicating that it is not ecocentric; however, the concept continues to evolve (Dangelico and Vocalelli 2017).

The Internet, packaging, and ecolabels are found to have an important role in green marketing strategy and closedloop supply chains as well as production processes being relevant to the marketing mix (Luchs and Swan 2011; Dangelico and Vocalelli 2017). The Product and Place of the 4P marketing mix should be jointly considered by companies (Dangelico and Vocalelli 2017). The meaning and characteristics of the last 3Ps of the 7Ps (Providing information, Processes, and Policies) are neither well developed, nor is there academic agreement on them (Dangelico and Vocalelli 2017). Thomas (2018) highlights that sustainable marketing should consider not only a product's internal relations such as price, consumer messages, and quality, but also its external relations with consumers such as brand loyalty.

Sustainability marketing has also been interpreted in terms of three conceptualisations which focus on production, promotion of sustainable lifestyles and behavioural changes, and the need for transformation of current institutions and norms as well as critical reflections (Kemper and Ballantine 2019).
Morris and Kirwan (2011) suggest that concerns about safety, provenance and quality are bringing certain consumers to pay extra for 'more natural' foods. Baritaux et al. (2016) extended the research of Morris and Kirwan (2011) to investigate how stakeholders understand, realise, utilise and negotiate the ecological dimension of food production. The three different forms of ecological embeddedness they identified depend on how the ecological dimensions of production are linked with environmental protection issues. These are

(1) practices linked with ecology are very consciously showcased as environmentally friendly,

(2) instead of environmental protection, practices and values associated with ecology are showcased through their impact on product quality, and

(3) technical and market constraints drive ecological 'disembeddedness'.

Saari et al. (2018) propose that actual product features should be used as a starting point for green marketing instead of focusing only on green consumers. Although some frameworks and features have been identified, there is no comprehensive or agreed characterisation of green, sustainable, or circular products (Waage et al. 2005; Leonidou et al. 2010; Luzio and Lemke 2013; Lemke and Luzio 2014). Circular products are not necessarily green products and vice versa (Gusmerotti et al. 2019). Similarly, it is unclear whether ecologically embedded products are circular, green and/or sustainable. Comparing ecologically embedded products to sustainable and circular products is hence identified as a means of investigating their characteristics and motivates the methods used in this research.

\section{Ecologically Embedded Strategy}

Products are the output of implemented strategy for manufacturing. Consequently, ecologically embedded products should reflect the ecologically embedded strategy which produced them. The previous section notes that the characteristics of ecologically embedded products are not clearly delineated. The following review will demonstrate that ecologically embedded strategy remains unrealised with various concepts capturing only certain elements of ecocentric manufacturing.

Operations strategy specifies how the resources of an organisation are to be used to support its business strategy (Fine and Hax 1985). The terms 'operations strategy' and 'manufacturing strategy' are often used synonymously. Manufacturing strategy may be considered a functional level strategy which looks at investing in and developing capabilities in manufacturing to support the organisation in competing in the market. 
Functional strategies are generally derived independently of one another and of the corporate strategy. However, a significant number of companies begin corporate sustainability initiatives on an operational level (Bonn and Fisher 2011) instead of integrating corporate sustainability at all business levels (Engert et al. 2016). The traditional perspective is that the challenge lies in integrating the various functional strategies so that they inform and fit the business strategy. That fit may take various forms such as matching, moderation and mediation (Venkatraman 1989). Process innovation has been hypothesised to have significant impact on firm performance in service economies (Malaviya and Wadhwa 2005; Gupta and Gupta 2019).

The main theoretical frameworks which have been used to explore the drivers of environmental practices are institutional theory (DiMaggio and Powell 1983) and the natural resource-based view of the firm (Hart 1995). The classic resource-based view and its variations are unable to reveal the mechanisms behind the design and execution of strategies in our current rapidly changing and complex knowledge-based, network economy in which competitive advantage is gained, lost and regained cyclically (Kraaijenbrink et al. 2010; McGrath 2013; Wójcik 2015). Dynamic capabilities emerged within the resource-based view to enable analysis of organisational change alignment with environmental dynamism using a new theoretical perspective (Teece et al. 1997).

Borland et al. (2016) extend the dynamic capabilities framework outside of a business ecosystem to global biophysical ecosystems by adding two new capabilities, remapping and reaping, to aid in closing the loop on business activity. Their framework considers business strategy, but not its relationship to corporate, operations or other functional strategies. It also fails to consider consumers outside of the context of consumer demand. However, their theory points to the need for the manufacturing and value-chain process to become a closed loop in order to be ecocentric.

Ecocentrism places intrinsic value on all living beings and is primarily concerned with protecting the health of ecosystems (Imran et al. 2014; Gray et al. 2018). There is a fundamental antagonism between the economic and social/ environmental logics of sustainability. It is therefore unremarkable that ecocentric approaches to business strategy are largely absent in the literature (Allen et al. 2019). Ecological embeddedness, a locally responsive strategy that is sensitive to local ecosystems, is an ecocentric approach with the potential to support strong sustainability (Landrum and Ohsowski 2018).

With respect to closing loops, the Ricoh case example cited by Borland et al. (2016) does not reflect issues with low toner cartridge return rates and third-party refillers which lead to piracy and counterfeiting within the toner business (Roper et al. 2017). A deeper investigation into the case of Ricoh (Hopkinson et al. 2018) illustrates that there is a complex and nuanced interplay amongst economic, environmental, and business continuity factors and highlights the importance of the marketing function in acting to change consumer culture as opposed to leaving $\mathrm{CE}$ responsibility with manufacturing and operation managers.

Penker (2006) confirms that ecological embeddedness affects marketing strategy, but this may require a strong actor to take initiative (Koistinen 2019). As ecological embeddedness implies a fundamentally different worldview, ecological embeddedness also signals an expansion in the role of marketing. This is supported by research on participants who viewed animated real-time water and electricity flow data and environmental conditions which resulted in enhanced perceptions of ecological embeddedness as well as perceptions of responsibility and impact (Petersen et al. 2018).

The circular economy (CE) and related concepts such as industrial ecology (Baas and Huisingh 2008; Lüdeke-Freund et al. 2018; Euchi et al. 2019), extended producer responsibility (Corsini et al. 2015), regenerative design (Lieder and Rashid 2016) and the cradle-to-cradle approach (Ünal and Shao 2019) capture elements of an ecocentric approach to manufacturing.

Geissdoerfer et al. (2017) investigated various contributions to the concept of $\mathrm{CE}$ to arrive at the following definition:

a regenerative system in which resource input and waste, emission, and energy leakage are minimised by slowing, closing, and narrowing material and energy loops. This can be achieved through longlasting design, maintenance, repair, reuse, remanufacturing, refurbishing, and recycling.

Consequently, CE is more focussed on resources and would better fit the broader definition of environmental embeddedness.

Gusmerotti et al. (2019) identify the need to examine how $\mathrm{CE}$ is integrated into business functions: from logistics to procurement, design, production, marketing and communication, as opposed to previous literature which has focused on anecdotal evidence for innovative business models that integrate CE principles. Their research suggests that managers are 'prompted by economic drivers' to integrate $\mathrm{CE}$ principles synergistically with business strategy.

Similarly, unlike ecological embeddedness in which both economic actors and the underlying ecology of production are intended to benefit, Geissdoerfer et al. (2017) find that $\mathrm{CE}$ prioritises the economic system and sustainability prioritises the TBL (Elkington 1997). Neither CE 
nor sustainability approaches may thus be considered ecocentric.

A business model represents a set of strategic decisions that define how value is created, transferred and captured in relationships with stakeholders such as suppliers and customers. A business model represents realised strategy, not future strategy (Casadesus-Masanell and Ricart 2010). Not every organisation has a strategy, i.e. a plan of action for the various contigencies that might arise. Tactics are the residual choices available to a firm after selecting a business model. Framing $\mathrm{CE}$ as a paradigm that can be implemented from a business model perspective is rare in the literature (Urbinati et al. 2017). In Table 1, a comparison is made among patterns, models and frameworks for circular economy business models from a lifecycle perspective for manufacturers alongside the framework for ecological embeddedness of agricultural production. Table 1 reflects the inadequacies of existing frameworks.
Table 1 indicates that the consumer use phase is not well conceived in $\mathrm{CE}$ for manufactured products. As noted by Lüdeke-Freund et al. (2018), customer preferences are generally not considered significant parameters of CEBM. In general, there is an omission of relational aspects from CEBM research which is unexpected as many such models rely on networks (Lüdeke-Freund et al. 2018).

Based on the gaps in Table 1, it is hypothesised that the framework of Morris and Kirwan (2011), which does include relational aspects, needs to be extended in order to be applicable to ecocentric approaches to manufacturing by becoming closed loop and including end of life. Consequently, a framework for ecological embeddedness of manufactured products is proposed consisting of understanding, realising, utilising, negotiating and reclaiming. The function that this framework should fulfil is comprehensive consideration of ecological relations at all lifecycle stages which answers subquestion 3 .

Table 1 A comparative summary of circular economy business model (CEBM) patterns based on life cycle compared with the ecological embeddedness framework (first column)

\begin{tabular}{|c|c|c|c|c|c|c|c|}
\hline $\begin{array}{l}\text { Ecological } \\
\text { embeddedness for } \\
\text { agricultural } \\
\text { production (Morris } \\
\text { and Kirwan 2011) }\end{array}$ & $\begin{array}{l}\text { ReSOLVE } \\
\text { framework } \\
\text { (Ellen } \\
\text { MacArthur } \\
\text { Foundation } \\
\text { 2015) }\end{array}$ & $\begin{array}{l}\text { Ecocentric } \\
\text { dynamic } \\
\text { capabilities } \\
\text { (Borland } \\
\text { et al. 2016) }\end{array}$ & $\begin{array}{l}\text { CE at micro- } \\
\text { level (Ghisellini } \\
\text { et al. 2016) }\end{array}$ & $\begin{array}{l}\text { Resource efficiency } \\
\text { strategies (Nußholz } \\
\text { 2017) }\end{array}$ & $\begin{array}{l}\text { Business } \\
\text { model } \\
\text { modifications } \\
\text { for CE } \\
\text { (Urbinati et al. } \\
\text { 2017) }\end{array}$ & $\begin{array}{l}\text { Major CEBM } \\
\text { patterns (Lüdeke- } \\
\text { Freund et al. 2018) }\end{array}$ & $\begin{array}{l}\text { CE model } \\
\text { (Ungerman } \\
\text { and } \\
\text { Dědková } \\
\text { 2019) }\end{array}$ \\
\hline \multirow{8}{*}{$\begin{array}{l}\text { Understanding } \\
\text { Realising } \\
\text { Utilising }\end{array}$} & \multicolumn{7}{|c|}{ Beginning of life-design, material input, production } \\
\hline & Regenerate & Sensing & Eco-design & Substituting virgin & \multirow[t]{6}{*}{ Value network } & & Renovation \\
\hline & Optimise & Seizing & Cleaner & material input & & & Reuse \\
\hline & Virtualise & Reconfiguring & Production & $\begin{array}{l}\text { Reducing material } \\
\text { use in products }\end{array}$ & & & Recycling \\
\hline & & & & Reducing emissions & & & \\
\hline & & & & $\begin{array}{l}\text { Reducing material } \\
\text { leakages }\end{array}$ & & & \\
\hline & & & & $\begin{array}{l}\text { Reducing new } \\
\text { demand (material } \\
\text { extraction) }\end{array}$ & & & \\
\hline & \multicolumn{7}{|c|}{ Middle of life-first consumer use phase } \\
\hline \multirow[t]{8}{*}{ Negotiating } & Share & & Consumer & Efficient Use & \multirow{3}{*}{$\begin{array}{l}\text { Customer } \\
\text { value } \\
\text { proposition } \\
\text { and } \\
\text { interface }\end{array}$} & \multirow{2}{*}{$\begin{array}{l}\text { Repair and } \\
\text { Maintenance }\end{array}$} & Renovation \\
\hline & & & Responsibility & $\begin{array}{l}\text { Increasing average } \\
\text { lifespan } \\
\text { Second life (repair) }\end{array}$ & & & $\begin{array}{l}\text { Reuse } \\
\text { Recycling }\end{array}$ \\
\hline & \multicolumn{6}{|l|}{ End of life } & \\
\hline & Loop & $\begin{array}{l}\text { Remapping } \\
\text { Reaping }\end{array}$ & $\begin{array}{l}\text { Waste } \\
\text { Management }\end{array}$ & $\begin{array}{l}\text { Second life } \\
\quad \text { (remanufacturing) }\end{array}$ & & $\begin{array}{l}\text { Reuse and } \\
\text { Redistribution }\end{array}$ & $\begin{array}{l}\text { Renovation } \\
\text { Reuse }\end{array}$ \\
\hline & & & & Material Recycling & & $\begin{array}{r}\text { Refurbishment and } \\
\text { Remanufacturing }\end{array}$ & Recycling \\
\hline & & & & & & Recycling & \\
\hline & & & & & & $\begin{array}{c}\text { Cascading and } \\
\text { Repurposing }\end{array}$ & \\
\hline & & & & & & Organic Feedstock & \\
\hline
\end{tabular}


To relate the framework to corporate, operations, business, marketing and sustainability strategy, an association is made with known comprehensive relational characteristics. Table 2 summarises these characteristics together with source literature.

Figure 1 represents the resulting proposed framework. In Fig. 1, the framework for investigating ecological embeddedness is transformed into the proposed framework for formulating ecologically embedded strategy based on Table 2.

The framework presented in Fig. 1 captures strategy relevant to ecocentric manufacturing. Manufacturing flexibility (Dey et al. 2019) and innovative activity (Melnik et al. 2019) are critical to Step 2. Other functional strategies such as financial strategy and research and development strategy are implicit in the framework and used to inform the steps. After all, resources must be allocated towards each of the steps (Sushil 2015). However, these generally anthropocentric strategies are subordinate to the overall aim of achieving ecologically embedded strategy for the production of ecologically embedded products. Although the framework is iterative to enable continuous improvement, as indicated in the introduction, time is of the essence to avoid premature extinction of industrial activity and/or an uninhabitable planet.

The overarching shortcoming of existing frameworks is a lack of consideration of relational aspects. The proposed framework is distinguished from previous frameworks that are simply descriptive of the actions to be taken at the various lifecycle stages to the consideration of the relationships and understanding required to achieve those actions. The most significant shortcoming of existing frameworks is a poor conception of the consumer use phase. Responsibility for the consumer use phase is

Table 2 Relating ecological embeddedness to firm strategy

\begin{tabular}{|c|c|c|c|c|c|}
\hline \multicolumn{3}{|c|}{ Ecological embeddedness } & \multicolumn{3}{|c|}{ Firm strategy levels for sustainability } \\
\hline Framework & Characteristics & References & Strategic level & Characteristics & References \\
\hline Understand & $\begin{array}{l}\text { Ecological values: intrinsic } \\
\text { and instrumental; } \\
\text { Production conditions related } \\
\text { to product quality and } \\
\text { characteristics }\end{array}$ & $\begin{array}{l}\text { Morris and } \\
\text { Kirwan (2011), } \\
\text { Hinchcliffe } \\
\text { et al. (2003), } \\
\text { Ilbery and } \\
\text { Kneafsey } \\
(2000)\end{array}$ & $\begin{array}{l}\text { Corporate } \\
\text { Strategy }\end{array}$ & $\begin{array}{l}\text { Maturity Level; } \\
\text { Attitude; } \\
\text { Values; Management Control } \\
\text { System and Sustainability } \\
\text { Control System }\end{array}$ & $\begin{array}{l}\text { Potrich et al. (2019), } \\
\text { Günther (2016), } \\
\text { Baumgartner and Ebner } \\
\text { (2010), Le Roux and } \\
\text { Pretorius (2016), Gond } \\
\text { et al. (2012) }\end{array}$ \\
\hline Realise & $\begin{array}{l}\text { Ecological production } \\
\text { processes and practices }\end{array}$ & $\begin{array}{l}\text { Kirwan et al. } \\
\text { (2017), } \\
\text { Baritaux, et al. } \\
\text { (2016), Morris } \\
\text { and Kirwan } \\
\text { (2011) }\end{array}$ & $\begin{array}{r}\text { Operations } \\
\text { Strategy }\end{array}$ & $\begin{array}{l}\text { Emission control; Remediation; } \\
\text { On-site recovery/reuse; } \\
\text { Design for Environment; } \\
\text { Green supply chain } \\
\text { management; Resource use } \\
\text { minimisation; Waste } \\
\text { minimisation; Life Cycle } \\
\text { Analysis (LCA), } \\
\text { Environmental Management } \\
\text { System (EMS) }\end{array}$ & Potrich et al. (2019) \\
\hline Utilise & $\begin{array}{l}\text { Influencing exchange process, } \\
\text { e.g. promotional materials } \\
\text { and activities, } \\
\text { environmental certification } \\
\text { schemes, conservation } \\
\text { activities }\end{array}$ & $\begin{array}{l}\text { Schifani, et al. } \\
\text { (2016), } \\
\text { Migliore et al. } \\
\text { (2015), Morris } \\
\text { and Kirwan } \\
\text { (2011) }\end{array}$ & $\begin{array}{l}\text { Business } \\
\text { Strategy }\end{array}$ & $\begin{array}{l}\text { Marketing and } \\
\text { Communication/green } \\
\text { marketing; e.g. eco-labelling; } \\
\text { environmental certifications; } \\
\text { environmental reports; media } \\
\text { disclosure; employee/customer } \\
\text { education }\end{array}$ & $\begin{array}{l}\text { Potrich et al. (2019), Saari } \\
\text { et al. (2018), Dangelico } \\
\text { and Vocalelli (2017), } \\
\text { Shrivastava (1995) }\end{array}$ \\
\hline Negotiate & $\begin{array}{l}\text { Value } \\
\text { Acceptance } \\
\text { Trust }\end{array}$ & $\begin{array}{l}\text { Schjøll (2017), } \\
\text { Wägeli and } \\
\text { Hamm (2016), } \\
\text { Morris and } \\
\text { Kirwan (2011) }\end{array}$ & Consumers & Buying Behaviour & $\begin{array}{l}\text { Sharma et al. (2019), Luzio } \\
\text { and Lemke (2013), Tsai } \\
\text { et al. (2012), Okada and } \\
\text { Mais (2010), Kotler and } \\
\text { Armstrong (2010), }\end{array}$ \\
\hline Reclaim & $\begin{array}{l}\text { Involvement } \\
\text { Engagement } \\
\text { Cooperation } \\
\text { Feedback } \\
\text { Reverse supply chain }\end{array}$ & Proposed & $\begin{array}{l}\text { Sustainability/ } \\
\text { CE } \\
\text { Strategy }\end{array}$ & $\begin{array}{l}\text { Recycling; Reuse; } \\
\text { Redistribution; Reverse } \\
\text { logistics; Refurbishment; } \\
\text { Remanufacturing; Cascading; } \\
\text { Repurposing; Organic } \\
\text { Feedstock }\end{array}$ & $\begin{array}{l}\text { Potrich et al. (2019), } \\
\text { Ungerman and Dědková } \\
\text { (2019), Lüdeke-Freund } \\
\text { et al. (2018) }\end{array}$ \\
\hline
\end{tabular}




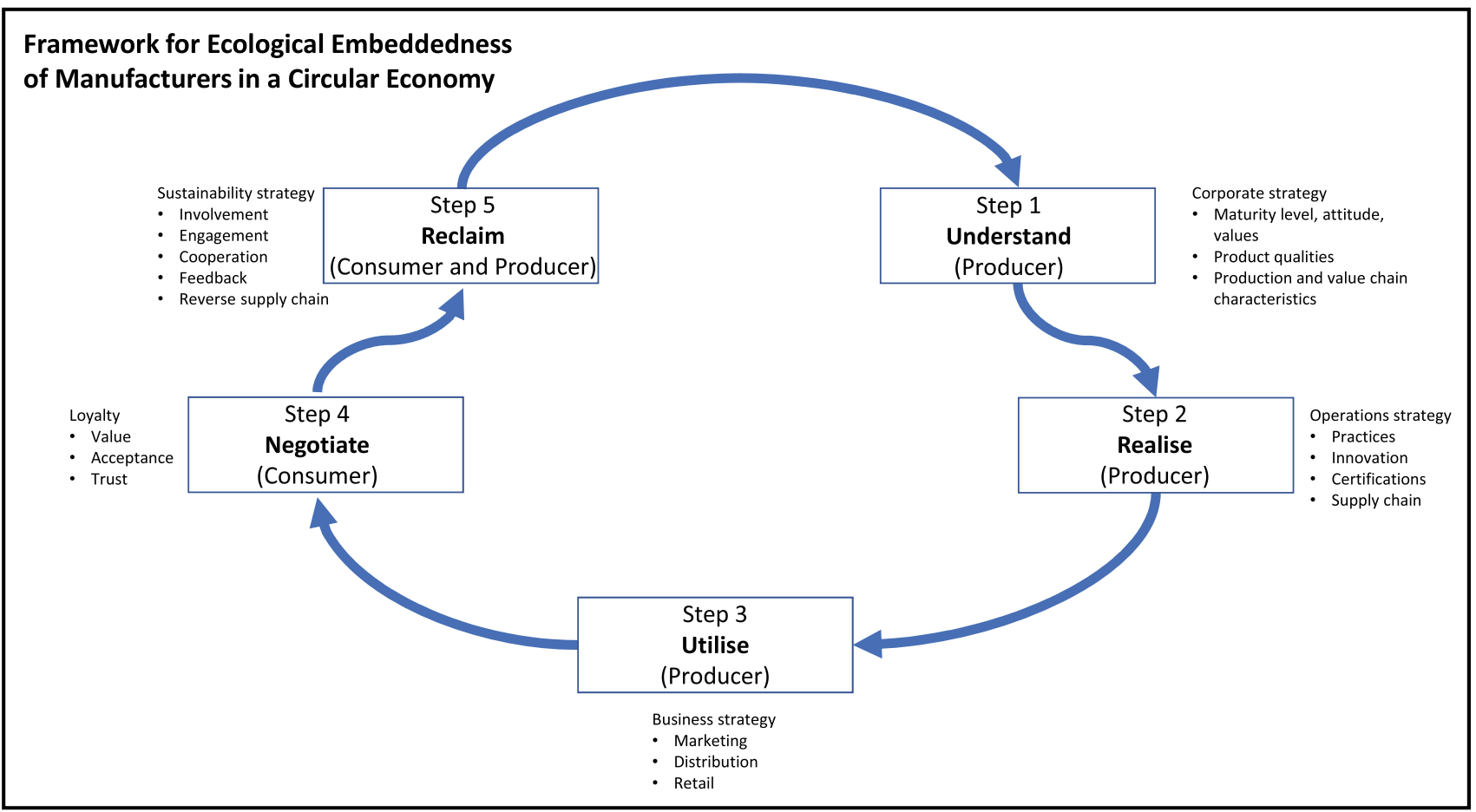

Fig. 1 Proposed framework for ecological embeddedness of manufactured products

predominantly placed on the consumer, whereas the proposed framework considers this phase as a process of negotiation built on the relationship between the manufacturer and consumer. Another shortcoming of existing frameworks is the failure to consider an ecological role for the marketing function in relation to the purchasing decision. In the proposed framework, the consumer use phase contributes to outcomes at end of life and informs the understanding of the producer in terms of product qualities which feed back into the business strategy and marketing function.

In summary, the following verification of the framework will address these gaps in the literature: The lack of empirical testing of ecological embeddedness for manufacturing as embeddedness is rarely described or tested and has yet to be considered outside of agricultural production. The lack of characterisation of ecologically embedded products as there is no comprehensive or agreed characterisation of green, sustainable, or circular products. Furthering knowledge about ecocentric marketing strategy as current perspectives in the literature are not ecocentric, the marketing approach of producers has rarely been explored and the consumer use phase is not well conceived. Furthering knowledge of ecologically embedded strategy as ecocentric approaches to business strategy are largely absent in the literature.

\section{Approach to Testing the Proposed Framework for Ecologically Embedded Strategy in Manufacturing}

Having proposed a framework for ecologically embedded strategy in manufacturing, the next step is to verify that the framework is feasible. This is accomplished through a twostage process. The first stage investigates farmers' market products to identify causal characteristics of ecologically embedded products to address subquestion 4 . These causal characteristics are then utilised in the second stage to identify manufactured products that could support the framework in response to subquestion 5 .

The aim of this research was neither verification of the information provided to consumers nor was it to establish consumer response, but rather an exploration of the information provided and how the information relates the strategy of the manufacturer/producer and their understanding and actions related to ecological embeddedness. The underlying motivation for this approach is that if certain information is absent, the consumer decision to purchase cannot be based on that missing information indicating a potential relational failure with respect to ecological embeddedness.

The UK is suitable for investigations related to ecological embeddedness for five major reasons: (1) the UK has developed the first practical framework and guidance for organisations to implement circular economy principles 
in BS 8001: 2017 (British Standards 2017) indicating that the UK is adopting a progressive approach to $\mathrm{CE}$; (2) famers' markets have the longest history in the UK where they were conceived in 1997 (Kirwan 2004); (3) the UK is still part of the European Union and so is bound by the strict rules and regulations related to protecting the environment; (4) producers at the Loughborough Farmers' Market are subject to vetting by the local council which represents the operating structure (Klimek et al. 2018); and (5) consumers are well-educated, technologically savvy and increasingly concerned with environmental issues (Walley et al. 2000; Gatersleben et al. 2019; Wood et al. 2019).

The units of analysis used in this research are manufacturers/producers. The sampling units are the products of these manufacturers/producers with respect to the information provided to consumers at the point of sale. The sampling frame for the initial data set is farmers' markets in England. Validation of the initial data set is achieved by expanding the cases under consideration to similar store products to achieve the required heterogeneity for analysis. The sampling frame for the final data set is manufacturers whose sustainable, green and/or circular products are sold in the UK.

Data collection took place at the Loughborough Farmers' Market and retailers in and surrounding Loughborough in the East Midlands of the UK in the latter half of 2019 (July-October). Loughborough is the largest town in the county of Leicestershire with a population of over 55,000. Socio-economic statistics are comparable to those of England with about 5\% higher home ownership and lower claiming of benefits than the national average, indicating that the area is relatively affluent. Consequently, the selection of Loughborough, on average, obviates significant financial barriers to green purchasing. The Loughborough Farmers' Market is frequented by producers that participate in farmers' markets throughout England, so that in addition to being a convenience sample, the Loughborough Farmers' Market also comprises a representative sample of products available at farmers' markets in England.

Data were also collected from the websites of retailers/manufacturers that sell sustainable, green and/or circular products in the UK. These retailers/manufacturers were identified using the Sainsbury's online shopping website feature for the selection of eco-friendly products. Sainsbury's was the only online grocery chain retailer located in Loughborough to provide such a search feature. Circular products were also identified from the websites of the Ellen MacArthur Foundation under 'partners' and 'case studies' and Circular Economy Club member organisations in the UK.
Sustainable products were labelled 'eco-friendly', sustainable and/or green. Circular products were those which the manufacturer self-identified as circular. Data were collected about the information available to consumers about the products at the point of sale which included data online on the manufacturer/producer website due to the ability of many people to access this information through their mobile phones at the point of sale. For some products, the point of sale was online.

Data collection at the Loughborough Farmers' Market employing observation and participant observation included notes about conditions at the site including weather and time of day, layout of the market, and conversations between vendors and consumers and between vendors and the researcher. Products and their associated information were noted including text on signs and banners, business cards were collected, and associated websites were investigated where available.

Data collection for sustainable, green and/or circular products employed observation and participant observation at retail points of sale, information available online and information available at online points of sale. Notes were made of the products including retailer information applying to the general product type, photographs of the product and/or information available, product-specific information located on, around or affixed to the product, conversations between the sales' representatives and the researcher and any available product-related pamphlets or similar information was collected. This was supplemented with information available about the product on the manufacturer and/or retailer website.

The decision-making process of consumers may be used to understand purchases. This process includes five stages which precede the actual purchase: need recognition and problem awareness, information search, evaluation of alternatives, purchase, and post-purchase evaluation (Kotler 2002). The motivation for the approach to data collection was to comprehensively include manufacturer-/ producer-based information search stage avenues accessible to consumers. Examples of data not included for being consumer-based are internet reviews and experiential information conveyed by friends and family.

Although all five of the decision-making stages are employed when the consumer is confronted with a new and complex purchase situation, a few steps may be skipped for routine purchases (Kotler and Armstrong 2010). This implies that habitual buying behaviour may be problematic for marketing in trying to change consumer purchasing (Solomon 2004) (p. 295). Figure 2 shows the four types of buying behaviour. The purpose of this research was not to analyse consumer decision-making, but as the type of buying behaviour is related to the product, buying behaviour is relevant in determining whether ecological 
Fig. 2 Four types of buying behaviour (Kotler and Armstrong 2010)
High consumer

involvement

Low consumer

involvement

\section{Significant \\ brand \\ differences \\ Few \\ brand \\ differences}

embeddedness is more or less present in the corresponding product types, e.g. high-involvement decisions would tend to imply that marketing needs to provide more information. For this reason, manufactured products were selected to represent each of the four types of buying behaviour.

\section{Stage 1 Method: Qualitative Comparative Analysis}

Qualitative comparative analysis (QCA) is context sensitive and can lay the groundwork for more demanding types of analyses. QCA rejects any form of permanent causality and equifinality supports multiple conjunctural causation. This moves the approach taken in this research away from simplistic, probabilistic causal reasoning. The maturity and robustness of generalisation are strongly dependent on the quality of the empirical data set constructed by the researcher. Nothing is supportive of conditions not included in the analysis not affecting the results. QCA is compatible with a more modest view on generalisation than statistical inference which allows very broad generalisations.

Although engineering researchers have not made substantial use of QCA, it provides a useful middle ground between statistical large- $\mathrm{N}$ studies and case study analysis and helps to determine causal relationships (Jordan et al. 2011). Crisp set QCA (csQCA) is the method utilised to uncover causal relationships leading to ecologically embedded products.

\section{Stage 2 Method: Process Tracing (PT)}

The output of csQCA is causal characteristics of ecologically embedded products which may then be utilised to identify suitable products for process tracing (PT) in support of the proposed framework for ecologically embedded strategy. Equifinality indicates that the proposed framework may not be the only path to ecologically embedded strategy; however, it is sufficient for this research to identify a feasible path (Walker et al. 2013). The identification of a feasible path is important due to the dearth of frameworks and tools that substantially engage with actual strategy development (Satyro et al. 2017; Grainger-Brown and Malekpour 2019).

Of the three types of PT, theory-testing PT is used as the proposed framework (Fig. 1) represents the theory to be tested based on the literature. PT for theory-testing consists of the following steps (Beach and Pedersen 2013):

(1) elaborating the hypothesised mechanisms;

(2) selecting an appropriate case; and

(3) substantiating the presence of the mechanism through gathered data which supports the proposed observable implications for all steps in the mechanism.

Case selection guidance for PT is based on the engagement of an analytical ideal type (Saylor 2018). If the case has contextual features that make it relatable to the ideal type, that case may be viably studied in relation to the ideal type, regardless of other characteristics (Saylor 2018). The identification of cases for PT was based on similarity with the results of csQCA of farmers' market products representing the ideal type.

\section{Results for Stage 1: Identifying Causal Characteristics of Ecologically Embedded Products}

The results and assessment for stage 1 are presented in A-F below.

A. Data collection at Loughborough Farmers' Market

The Loughborough Farmers' Market is held on the second Wednesday of each month between 9 am and $3 \mathrm{pm}$. A basic stall/gazebo costs $£ 18$ per day. Traders need public liability with a minimum of $£ 5 \mathrm{~m}$ cover. The Loughborough Farmers' Market is described by Charnwood Borough Council as

"Producers from across the Midlands come to Loughborough's Farmers' market to sell a range of 
interesting, organic and healthy food and drink. Traders attending sell a wide range of excellent local produce such as meat, bread, fruit and vegetables, cheeses, honey, eggs, homemade sauces and preserves." (Charnwood 2019)

As noted by Figueroa-Rodríguez et al. (2019), there is no single type of farmers' market, and participant sellers such as food processors may be present. The Loughborough Farmers' Market was visited from July to October 2019. The late summer dates were intended to capture agricultural harvest, and the date in October was to determine whether there was any change to how information was presented with the corresponding influx of university students. Both habitual and variety-seeking buying behaviour were observed. Observation was discontinued when it appeared that a point of saturation had been reached as no new information was being obtained. Vendors present at the Market during this time period are listed in Table 3. Products listed under 'Other' include dry felting, craft items and patisserie/baked goods. Products were initially all considered ecologically embedded.

Information was collected about the products being sold using observation and participant observation of market stalls and corresponding websites where available. It has been proposed that consumer purchasing behaviour is rooted in the information exchange between consumers and vendors (Carson et al. 2016). Consumer informationseeking preferences have been investigated at a university farmers' market, indicating that information related to food quality, environmental and social impacts and animal welfare is desired (Fehrenback and Wharton 2012), but this was not a direct study of what information is actually available at the market. Similarly, Svenfelt and CarlssonKanyama (2010) use interviews (31 in total plus 10 semistructured interviews) and find few examples of

Table 3 List of Loughborough Farmers' Market participants

\begin{tabular}{|c|c|c|c|}
\hline Product(s) & Producer & Production & Website \\
\hline Cutting boards and coasters & Crafting Supplies Outlet (CSO) & Manufacture & https://www.craftingsuppliesoutlet.com/ \\
\hline Candles & First Light Candles (FLC) & Manufacture & https://www.firstlightcandles.co.uk/ \\
\hline Hats and related items & bizzy lizzy (BL) & Manufacture & https://www.bizzylizzyhats.co.uk/ \\
\hline Wooden shelves & The Rustic Design Shed (TRDS) & Manufacture & \\
\hline Crafts and food products & Country Markets (CM) & Manufacture/agriculture & https://www.country-markets.co.uk/ \\
\hline Goat meat & Black Goat Farm (BGF) & Agriculture & http://www.blackgoatfarm.co.uk/ \\
\hline Cheese & The Melton Cheeseboard (TMC) & Manufacture & http://meltoncheeseboard.co.uk/ \\
\hline Organic meat & Pick’s Organic Farm (POF) & Agriculture & https://picksorganic.co.uk/ \\
\hline Pies & Brockleby's (B) & Manufacture/agriculture & https://www.brocklebys.co.uk \\
\hline Honey & Beekeeper $(\mathrm{H})$ & Agriculture & \\
\hline $\begin{array}{l}\text { Dry felting/patisserie/baked goods/ } \\
\text { craft items }\end{array}$ & Various (Other) & Manufacture & various \\
\hline
\end{tabular}

contributions to the ecological knowledge of shoppers at a farmers' market in Stockholm. More recently, the ethnographic approach of Garner (2018) to farmers' markets in the Midwestern USA found that explicit discussions of sustainability were rare during sales exchange and that explicit examples of sustainability marketing that did occur were on signs and pamphlets. This was corroborated at the Loughborough Farmers' Market and extended to the finding that sustainability information was located on websites which were referenced in signs and banners at the farmers' market stalls. Sustainability information was also provided verbally when it was requested.

Garner (2018) found that concepts such as environmentally conscious, local, organic and chemical free served as proxies for the word 'sustainability' as sustainability may be seen as too complex a set of ideas that guide production philosophy and practices as opposed to a marketing concept. 'Sustainability' was also not a term that appeared in the data collected for products at the Loughborough Farmers' Market.

\section{B. Coding of Loughborough Farmers' Market Data}

Open, axial and selective coding (Charmaz 2006) and thematic analysis (Braun and Clarke 2006) were used to code the data. Open coding of the data resulted in the following subcategories: provenance, quality, wholesome, community, price, services, recognition and conservation. The subcategories reflect relationships of the data with ecological embeddedness which are conceptually easier to identify than with sustainability. The descriptions of these subcategories reflect the viewpoint presented in the literature review that ecological embeddedness concerns the relationships between economic actors and the underlying ecology of production such that a benefit is produced to both. The subcategories and their descriptions are as follows: 
(1) 'Provenance' describes environmentally friendly sourcing of inputs and production. Terms such as 'local', 'seasonal', 'cruelty free', 'organic', 'raised as nature intended', 'direct from', 'home-made', 'homegrown', 'minimising food miles', 'reclaimed wood from...' and 'handcrafted' are examples.

(2) 'Quality' refers to products that are fresh, tasty, made with skill, talent and/or traditional methods linked to environmentally friendly usage by minimising waste or environmental superiority to comparable manufactured products. Quality may be communicated through the presentation of the product such as showing a cross section or by offering 'taste before you buy'.

(3) The 'wholesome' subcategory refers to terms such as 'healthy', 'vegan' and products that are 'natural' with related terms such as 'no pesticides', 'not produced using industrial solvents', 'healthy alternative to...' and may be represented through the provision of dietary information. 'Organic' is considered a production method for the 'provenance' subcategory, but perceived health benefits may be behind purchase intent (Hughner et al. 2007).

(4) A consideration of societal aspects of the farmers' market in promoting ecological products is captured by the subcategory 'community', e.g. 'promotes community enterprise as a solution to local food needs', 'popular, lively meeting place', 'reconnect consumers to the land', the creation of clubs.

(5) In addition to fixed pricing, unlike conventional retailers, 'price' may be variable and sensitive to the customer, e.g. 'affordable prices for individual customers', 'discuss what you would like to pay', time of day discount.

(6) 'Services' are unique differentiators for the product, e.g. 'personalised', 'custom', 'do not offer online shopping as ... customers prefer to talk to a human being', cooking advice and statements about mainstream competitors, e.g. 'major supermarkets...restrict consumer choice and sell depersonalized food'.

(7) 'Recognition' refers to certifications, awards and registrations, reference to date of establishment or history, e.g. 'since 1999', 'for more than 100 years'.

(8) 'Conservation' refers to information provided to consumers about environmental impact beyond product care or conventional recycling, e.g. 'glass jars and lids can be ... reused', Asian Hornet threat, 'reclaimed', 'rescued' and organic-circular (De Young 1986).

Axial coding related each of the subcategories to a stage of the product lifecycle: beginning of life (BOL), middle of life (MOL) and end of life (EOL) reflecting a 'theoretical' thematic analysis (Braun and Clarke 2006) under the selective code 'ecologically embedded products' as shown in Fig. 3.

\section{Data Collection at Local Grocery Store}

The next step was to identify products down the street from the Loughborough Farmers' Market at a local store that were categorically similar in order to enable a most similar, different outcome (MSDO) approach (Berg-Schlosser and De Meur 2009) to investigate causality. For CM preserves were considered and as goat meat was not available, BGF does not have a corresponding product. Table 4 lists the store products and their characteristics based on the opencoding subcategories identified for the Loughborough Farmers' Market products.

C. Data analysis for Loughborough Farmers' Market products and categorically similar store products

csQCA reduces codes to binary conditions in which value 1 indicates that a condition is met, whereas value 0 indicates that a condition is not met. The simplified Truth Table shown in Table 5 is for both Loughborough Farmers' Market and store products. Price was not included as a variable must vary and all items had a price (condition was met). 'Other' products from the Loughborough Farmers' Market were initially considered ecologically embedded, but this led to a contradiction with 'msbp' which was resolved by reconsidering the outcome as not ecologically embedded (Rihoux and De Meur 2009).

Four complete minimisation procedures were performed using Tosmana software (Cronqvist) as recommended by Rihoux and De Meur (2009). The descriptive formulas (minimising [1] configurations and minimising [0] configurations without including non-observed cases (logical remainders)) had no simplifying assumptions. Running the minimisation procedures with logical remainders resulted in

$\operatorname{PROV}\{1\}+\mathrm{QUAL}\{1\} * \mathrm{WHOL}\{1\} \rightarrow \operatorname{ECOEMBED}\{1\}$
$(\mathrm{POF}+\mathrm{TMC}, \mathrm{CM}+\mathrm{CSO}+\mathrm{BL}+\mathrm{B}+\mathrm{H}+\mathrm{BGF}, \mathrm{TRDS}+\mathrm{FLC})$

$\operatorname{PROV}\{0\}+\operatorname{SERV}\{0\} * \operatorname{COM}\{0\} * \operatorname{CONS}\{0\} \rightarrow \operatorname{ECOEMBED}\{0\}$ (Other, msbp + ch, aw + bls, skp + dbs + hd, oed, kh, bclb)

'Recognition' is not included in either formula. Formula 1 indicates that there are two 'paths' to ecological embeddedness: 'Provenance' or 'Quality' and 'Wholesome'. Hence, Formula 1 provides the answer to subquestion 4 in terms of these causal conditions.

Similarly, lack of 'Provenance' or lack of 'Service' and 'Community' and 'Conservation' are the two paths to 


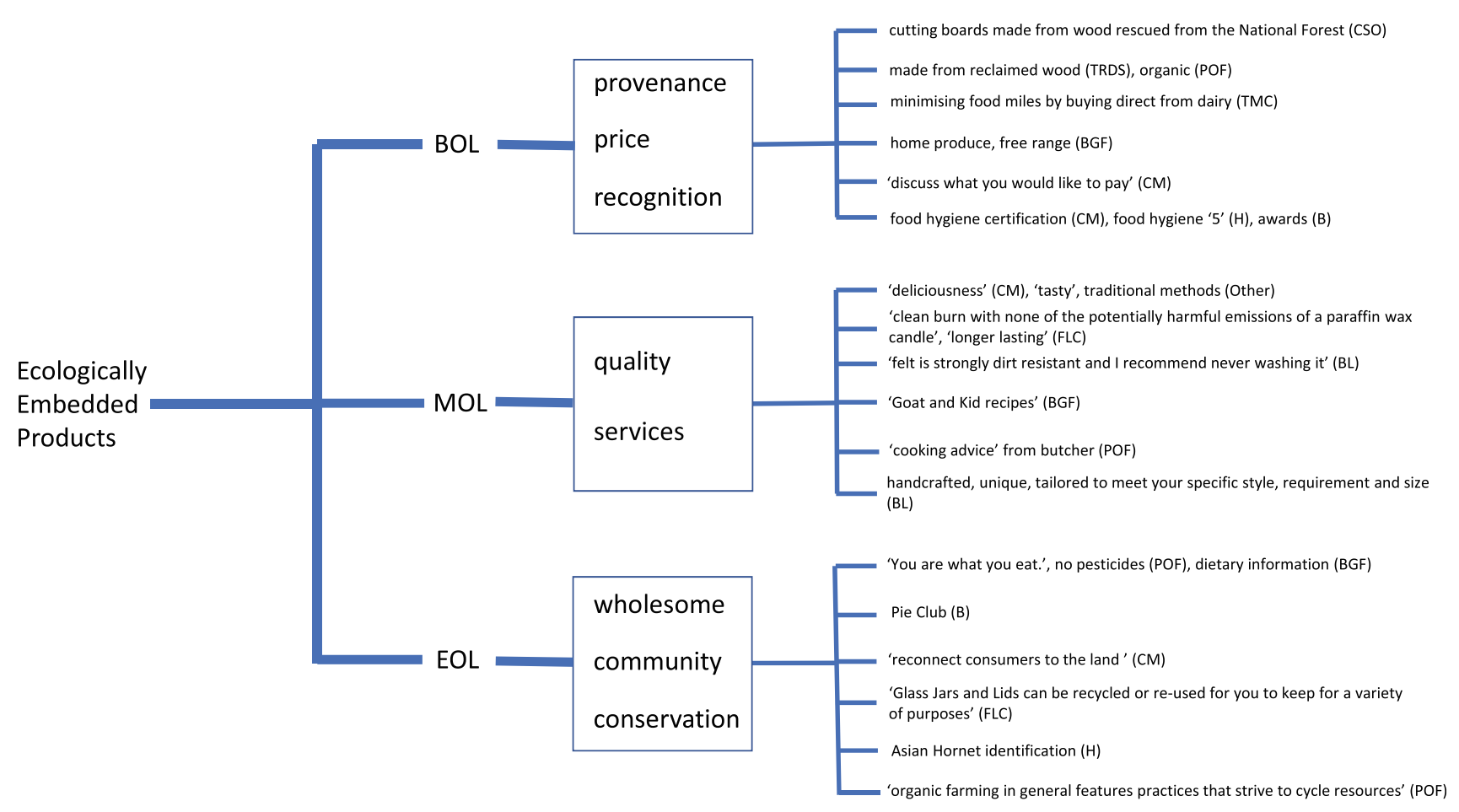

Fig. 3 Classification of product information based on lifecycle with examples

products that are not ecologically embedded. As this research focuses on products that are ecologically embedded, Formula 2 remains of theoretical interest but will not be used in subsequent analysis.

D. Assessing the output of csQCA

There are two main measurements that may be used to assess the output Formulas of csQCA: consistency and coverage (Jordan et al. 2011). For both Formula 1 and Formula 2, consistency is 1 which exceeds the typically relied upon score of 0.75 . Having established consistency, it is reasonable to examine coverage (Ragin 2006) which is again 1 indicating very high coverage for Formula 1 and Formula 2. High coverage scores indicate that the configurations are consistent with the outcome as supported by the cases (Poveda and Martínez 2013). There is no unique coverage for the alternate paths.

E. Assessing consistency with the proposed framework for ecologically embedded strategy

Although causal conditions were identified in Formulas 1 and 2, it is still necessary to confirm that the Farmers' Market Products are consistent with the proposed framework for ecologically embedded strategy. Ecologically embedded farmers' market products should at least yield data in the first four steps of the framework (understandnegotiate). Confirmation of correspondence with the ecologically embedded strategy framework is demonstrated in
Table 6. These results indicate that, aside from 'Other', the farmers' market products are ecologically embedded and not practically reclaimed. However, circularity (reclaiming) is a consideration that is present for relevant forms of production or packaging as illustrated by POF and FLC, respectively.

\section{Results for Stage 2-Process Tracing Confirmation of the Proposed Framework for Ecologically Embedded Strategy of Manufacturers}

Having identified causal characteristics of ecologically embedded products (Formula 1), these may now be used for the identification of appropriate cases of manufactured products that could verify the framework for ecologically embedded strategy formulation in manufacturing. Initially, cases to which PT may be applied need to be identified in an inclusive and unbiased manner. Following this, PT may be applied to the selected cases to answer subquestion 5whether or not it is feasible to extend the framework for ecological embeddedness to strategy formulation in manufacturing. Success of the application of PT will identify the benefits of ecologically embedded manufacturing in answer to subquestion 6 .

The results and assessment for stage 2 are presented in A-E below. 
Table 4 Store products categorically similar to Loughborough Farmers' Market products

\begin{tabular}{|c|c|c|c|c|c|c|c|}
\hline Product & Prov & $\operatorname{Rec}$ & Qual & Serv & Whol & Com & Cons \\
\hline $\begin{array}{l}\text { Bamboo large cutting } \\
\text { board (bclb) }\end{array}$ & Made in China & No & No & No & No & No & No \\
\hline $\begin{array}{l}\text { White bean vanilla } \\
\text { candle } 105 \mathrm{~g} \text { (aw) }\end{array}$ & Made in China & No & No & No & $\begin{array}{l}\text { infused with } \\
\text { natural } \\
\text { essential } \\
\text { oils }\end{array}$ & No & No \\
\hline $\begin{array}{l}\text { Knitted hat one size } \\
(\mathrm{kh})\end{array}$ & Made in China & No & No & No & No & No & No \\
\hline $\begin{array}{r}\text { Oak effect retro } \\
\text { drawers (oed) }\end{array}$ & Made in China & No & No & No & No & No & No \\
\hline $\begin{array}{l}\text { Seedless bramble } \\
\text { preserve } 340 \mathrm{~g} \\
(\mathrm{msbp})\end{array}$ & $\begin{array}{l}\text { Made in Scotland } \\
\text { in copper pans }\end{array}$ & since 1938 & $\begin{array}{l}\text { delicious, use only the finest } \\
\text { seedless brambles, using } \\
\text { traditional copper pans }\end{array}$ & No & No & No & No \\
\hline $\begin{array}{l}\text { British lamb steaks } \\
\text { from trusted } \\
\text { farmers } 300 \mathrm{~g}(\mathrm{bls})\end{array}$ & $\begin{array}{l}\text { Produced in UK. } \\
\text { Origin UK. }\end{array}$ & No & $\begin{array}{l}\text { a prime cut selected for flavour } \\
\text { and tenderness }\end{array}$ & No & No & No & No \\
\hline $\begin{array}{l}\text { Delicatessen Blue } \\
\text { Stilton (dbs) }\end{array}$ & $\begin{array}{l}\text { Produced in UK } \\
\text { using milk from } \\
\text { the UK }\end{array}$ & $\begin{array}{l}\text { Protected Designation of } \\
\text { Origin symbol, Stilton } \\
\text { Cheese Makers Association }\end{array}$ & No & No & No & No & No \\
\hline $\begin{array}{l}\text { steak and kidney pie } \\
200 \mathrm{~g} \text { (skp) }\end{array}$ & $\begin{array}{l}\text { Produced in the } \\
\text { U.K., using beef } \\
\text { from the U.K. }\end{array}$ & No & $\begin{array}{l}\text { our expert bakers...just the way } \\
\text { you'd make it at home }\end{array}$ & No & No & No & No \\
\hline $\begin{array}{l}\text { clear honey } 454 \mathrm{~g} \\
\text { (ch) }\end{array}$ & Produce of non-EU & No & No & No & $\begin{array}{l}\text { naturally } \\
\text { sweet, } \\
\text { made } \\
\text { naturally }\end{array}$ & No & No \\
\hline $\begin{array}{l}\text { Halloween } \\
\text { doughnuts } 4 \text { pack } \\
\text { (hd) }\end{array}$ & No & No & No & No & No & No & No \\
\hline
\end{tabular}

Table 5 Simplified Truth Table (UPPER CASE = Loughborough Farmers' Market product, lower case $=$ store product, Other $=$ Loughborough Farmers' Market products that are not ecologically embedded) (Cronqvist)

\begin{tabular}{|c|c|c|c|c|c|c|c|c|}
\hline CASE ID & PROV & REC & QUAL & SERV & WHOL & $\mathrm{COM}$ & CONS & ECOEMBED \\
\hline hd, oed, kh, bclp & 0 & 0 & 0 & 0 & 0 & 0 & 0 & 0 \\
\hline ch, aw & 0 & 0 & 0 & 0 & 1 & 0 & 0 & 0 \\
\hline bls, skp & 0 & 0 & 1 & 0 & 0 & 0 & 0 & 0 \\
\hline $\mathrm{dbs}$ & 0 & 1 & 0 & 0 & 0 & 0 & 0 & 0 \\
\hline Other, msbp & 0 & 1 & 1 & 0 & 0 & 0 & 0 & 0 \\
\hline FLC & 1 & 0 & 1 & 0 & 1 & 0 & 1 & 1 \\
\hline BGF, TRDS & 1 & 0 & 1 & 1 & 1 & 0 & 1 & 1 \\
\hline $\mathrm{H}$ & 1 & 1 & 1 & 0 & 1 & 0 & 1 & 1 \\
\hline B & 1 & 1 & 1 & 0 & 1 & 1 & 0 & 1 \\
\hline BL & 1 & 1 & 1 & 1 & 1 & 0 & 0 & 1 \\
\hline $\mathrm{CSO}$ & 1 & 1 & 1 & 1 & 1 & 0 & 1 & 1 \\
\hline TMC, CM & 1 & 1 & 1 & 1 & 1 & 1 & 0 & 1 \\
\hline POF & 1 & 1 & 1 & 1 & 1 & 1 & 1 & 1 \\
\hline
\end{tabular}

Created with Tosmana version 1.61 
Table 6 Categorisation of information based on the extended ecological embeddedness framework

\begin{tabular}{|c|c|c|c|c|c|}
\hline \multirow[b]{2}{*}{ Producer } & \multicolumn{5}{|c|}{ Ecological Embeddedness Framework } \\
\hline & Understand & Realise & Utilise & Negotiate & Reclaim \\
\hline $\begin{array}{l}\text { Crafting } \\
\text { Supplies } \\
\text { Outlet (CSO) }\end{array}$ & $\begin{array}{l}\text { Wood used for cutting } \\
\text { boards is rescued } \\
\text { from the local } \\
\text { national forest }\end{array}$ & $\begin{array}{l}\text { Local production; } \\
\text { personalised or unique } \\
\text { designs are burned into } \\
\text { the wood }\end{array}$ & $\begin{array}{l}\text { Promoted as made from } \\
\text { rescued wood; } \\
\text { personalisation or } \\
\text { custom work available }\end{array}$ & $\begin{array}{l}\text { Information } \\
\text { verbally at } \\
\text { farmers' } \\
\text { market stand } \\
\text { regarding } \\
\text { wood; custom } \\
\text { cuts on website }\end{array}$ & $\begin{array}{l}\text { No reclamation of } \\
\text { product; damaged } \\
\text { goods are responsibility } \\
\text { of carrier }\end{array}$ \\
\hline $\begin{array}{l}\text { First Light } \\
\text { Candles } \\
\text { (FLC) }\end{array}$ & $\begin{array}{l}\text { Vegan, cruelty free, } \\
\text { natural }\end{array}$ & $\begin{array}{l}\text { Hand poured in kitchen } \\
\text { using natural soy wax } \\
\text { and } 100 \% \text { essential oils }\end{array}$ & $\begin{array}{l}\text { Promoted as clean burning } \\
\text { and longer lasting }\end{array}$ & $\begin{array}{l}\text { Information at } \\
\text { farmers' } \\
\text { market stand } \\
\text { and website }\end{array}$ & $\begin{array}{l}\text { Product not reclaimable; } \\
\text { glass noted on website } \\
\text { as reusable or } \\
\text { recyclable; reclamation } \\
\text { of glass for refilling will } \\
\text { be considered if } \\
\text { sufficient regular } \\
\text { clientele is established }\end{array}$ \\
\hline $\begin{array}{l}\text { bizzy lizzy } \\
\text { (BL) }\end{array}$ & $\begin{array}{l}\text { Finest quality natural } \\
\text { materials } \\
\text { (including local } \\
\text { wool) }\end{array}$ & $\begin{array}{l}\text { Felt hats are handmade in } \\
\text { workroom at home; } \\
\text { custom orders available } \\
\text { tailored to specific } \\
\text { style, requirement and } \\
\text { size }\end{array}$ & $\begin{array}{l}\text { Handmade felt (wet } \\
\text { felting) promoted as } \\
\text { strong, comfortable to } \\
\text { wear, no itching, } \\
\text { moulding to the wearer } \\
\text { and becoming better } \\
\text { with age, strongly dirt } \\
\text { resistant with washing } \\
\text { not recommended }\end{array}$ & $\begin{array}{l}\text { Information at } \\
\text { farmers' } \\
\text { market stand } \\
\text { and website }\end{array}$ & $\begin{array}{l}\text { Returns and exchanges for } \\
\text { products that are not } \\
\text { custom or personalised, } \\
\text { conditions apply }\end{array}$ \\
\hline $\begin{array}{l}\text { The Rustic } \\
\text { Design Shed } \\
\text { (TRDS) }\end{array}$ & $\begin{array}{l}\text { Made from reclaimed } \\
\text { wood }\end{array}$ & $\begin{array}{l}\text { Handmade shelving using } \\
\text { thick pieces of wood; } \\
\text { custom orders accepted }\end{array}$ & $\begin{array}{l}\text { Very durable appearance } \\
\text { due to thickness of } \\
\text { wood; promoted as } \\
\text { made of reclaimed } \\
\text { wood when asked about } \\
\text { source }\end{array}$ & $\begin{array}{l}\text { Information at } \\
\text { farmers' } \\
\text { market stand }\end{array}$ & $\begin{array}{l}\text { reclamation of product } \\
\text { unanticipated }\end{array}$ \\
\hline $\begin{array}{l}\text { Country } \\
\text { Markets } \\
(\mathrm{CM})\end{array}$ & $\begin{array}{l}\text { Reconnect consumers } \\
\text { to the land }\end{array}$ & $\begin{array}{l}\text { Locally grown, home } \\
\text { produced, free range }\end{array}$ & $\begin{array}{l}\text { Promoted as home } \\
\text { produced, fresh and } \\
\text { seasonal and supporting } \\
\text { local community }\end{array}$ & $\begin{array}{l}\text { Information at } \\
\text { farmers' } \\
\text { market stand } \\
\text { and website }\end{array}$ & $\begin{array}{l}\text { Food products consumed } \\
\text { and not reclaimable/ } \\
\text { craft products } \\
\text { unspecified for } \\
\text { reclamation }\end{array}$ \\
\hline $\begin{array}{l}\text { Black Goat } \\
\text { Farm (BGF) }\end{array}$ & $\begin{array}{l}\text { Raised as nature } \\
\text { intended, highest } \\
\text { ethical standards }\end{array}$ & $\begin{array}{l}\text { Free range at local farm, } \\
\text { quality outdoor grazing } \\
\text { and shelter }\end{array}$ & $\begin{array}{l}\text { Promoted as local, quality, } \\
\text { tasty and nutritious } \\
\text { meat from happy goats }\end{array}$ & $\begin{array}{l}\text { Information at } \\
\text { farmers' } \\
\text { market stand } \\
\text { and website }\end{array}$ & $\begin{array}{l}\text { Product consumed and not } \\
\text { reclaimable }\end{array}$ \\
\hline $\begin{array}{l}\text { The Melton } \\
\text { Cheeseboard } \\
\text { (TMC) }\end{array}$ & $\begin{array}{l}\text { Supply chain ecology, } \\
\text { quality, } \\
\text { provenance, } \\
\text { commitment to } \\
\text { local producers }\end{array}$ & $\begin{array}{l}\text { Buying directly from } \\
\text { cheesemakers to } \\
\text { minimise food miles, } \\
\text { grading at dairy to } \\
\text { TMC specifications; } \\
\text { sourcing many cheeses } \\
\text { from local dairies }\end{array}$ & $\begin{array}{l}\text { Promoted as low food } \\
\text { miles; provenance; taste } \\
\text { before you buy; no } \\
\text { online shopping service } \\
\text { to ensure personal } \\
\text { service }\end{array}$ & $\begin{array}{l}\text { Information at } \\
\text { farmers' } \\
\text { market stand } \\
\text { and website }\end{array}$ & $\begin{array}{l}\text { Product consumed and not } \\
\text { reclaimable }\end{array}$ \\
\hline $\begin{array}{l}\text { Pick's Organic } \\
\text { Farm (POF) }\end{array}$ & $\begin{array}{c}\text { Core values and } \\
\text { environmental } \\
\text { stewardship }\end{array}$ & $\begin{array}{l}\text { Organic from local farm, } \\
\text { precise processing and } \\
\text { production standards } \\
\text { with no irradiation, } \\
\text { industrial solvents or } \\
\text { synthetic food additives }\end{array}$ & Promoted as organic & $\begin{array}{l}\text { Information at } \\
\text { farmers' } \\
\text { market stand } \\
\text { and website }\end{array}$ & $\begin{array}{l}\text { Product consumed and not } \\
\text { reclaimable; } \\
\text { production: cycle } \\
\text { resources in organic } \\
\text { farming }\end{array}$ \\
\hline Brockleby’s (B) & $\begin{array}{l}\text { Believe food with } \\
\text { provenance is good } \\
\text { for you and the } \\
\text { environment }\end{array}$ & $\begin{array}{l}\text { Handmade pies with } \\
\text { locally sourced meat }\end{array}$ & $\begin{array}{l}\text { Samples, product cut in } \\
\text { half for display; } \\
\text { promoted as food with } \\
\text { provenance }\end{array}$ & $\begin{array}{l}\text { Information at } \\
\text { farmers' } \\
\text { market stand } \\
\text { and website }\end{array}$ & $\begin{array}{l}\text { Product consumed and not } \\
\text { reclaimable }\end{array}$ \\
\hline
\end{tabular}


Table 6 continued

\begin{tabular}{|c|c|c|c|c|c|}
\hline \multirow[b]{2}{*}{ Producer } & \multicolumn{5}{|c|}{ Ecological Embeddedness Framework } \\
\hline & Understand & Realise & Utilise & Negotiate & Reclaim \\
\hline Beekeeper $(\mathrm{H})$ & $\begin{array}{l}\text { Value local } \\
\text { environment }\end{array}$ & Locally produced & $\begin{array}{l}\text { One laminated } \\
\text { information sheet about } \\
\text { threat of Asian hornet to } \\
\text { local bees at stand }\end{array}$ & $\begin{array}{l}\text { Information at } \\
\text { farmers' } \\
\text { market stand }\end{array}$ & $\begin{array}{l}\text { Product consumed and not } \\
\text { reclaimable }\end{array}$ \\
\hline various (Other) & $\begin{array}{l}\text { Value use of finest } \\
\text { quality ingredients, } \\
\text { authentic and } \\
\text { traditional recipes, } \\
\text { unique products but } \\
\text { no connection to } \\
\text { ecology }\end{array}$ & $\begin{array}{l}\text { Traditional skills, } \\
\text { handmade and/or baked } \\
\text { fresh } 7 \text { days a week but } \\
\text { production not related } \\
\text { to ecology }\end{array}$ & $\begin{array}{l}\text { Promotion based on } \\
\text { history and tradition, } \\
\text { taste but not ecology }\end{array}$ & $\begin{array}{l}\text { Information at } \\
\text { farmers' } \\
\text { market stand } \\
\text { and website }\end{array}$ & $\begin{array}{l}\text { Product consumed and not } \\
\text { reclaimable }\end{array}$ \\
\hline
\end{tabular}

A. Identification of potential manufactured products for the application of PT

As broad a range of products as possible was identified in an unbiased manner based on manufacturer self-identification as selling sustainable, green, and/or circular products in the UK. The products were located through the Sainsbury's online shopping website feature for the selection of eco-friendly products, the Ellen MacArthur Foundation website and Circular Economy Club member organisations in the UK. Table 7 identifies the set of manufactured products from which appropriate cases for PT could be selected.

Buying behaviour classification was based on literature (Michaelidou and Dibb 2009; Munthu 2009; Sharma 2014; Sevanandee and Damar-Ladkoo 2018; Kunamaneni et al. 2019). High consumer involvement was assumed if the product price exceeded the average monthly salary (£2921.50) determined from average advertised UK salaries (Scott 2019).

\section{B. Data analysis for manufactured products}

The information in Table 7 may be used to construct a Truth Table similar to that of farmers' market products but using only the causal characteristics identified in Formula 1 together with reclamation. The corresponding Truth Table is presented in Table 8 in which ecological embeddedness is considered in terms of provenance, quality, wholesomeness and reclamation, where reclamation represents return of the product to the manufacturer at the end of life.

From Table 8, the products (cases) identified for PT are jeans and mobile phone for the reasons that they present the hypothesised reclamation and satisfy causal conditions for being ecologically embedded. MUD jeans demonstrates both causal paths in Formula 1, whereas Fairphone satisfies only the 'provenance' causal path.

C. Substantiating the mechanism for ecologically embedded strategy in manufacturing

The next step is to substantiate the presence of the mechanism (Fig. 1) through gathered data which supports the proposed observable implications for all steps in the mechanism. Evaluating evidence involved three steps: (1) predicting the empirical fingerprints, (2) collecting and assessing whether the predicted evidence was found and (3) evaluating whether the evidence is trustworthy.

Table 9 presents evidence for MUD jeans and Fairphone. The circularity of MUD jeans is apparent in the evidence; however, it is unclear if or how the products that Fairphone recycles are subsequently incorporated into their own supply chain or what happens to phones that can be reused. Whereas MUD jeans exhibits production innovation, Fairphone is focused on material sourcing and employee well-being throughout its supply chain.

\section{Establishing trustworthiness of PT}

Trustworthiness is established by four 'tests': straw-inthe-wind, hoop, smoking gun and doubly decisive (Van Evera 1997; Bennett 2010; Collier 2011). Applying these tests to the evidence indicates a high level of trustworthiness as the evidence is doubly decisive (high certainty, high uniqueness). Consequently, together with the fact that it was possible to identify suitable cases, the feasibility of extending the framework for ecological embeddedness to strategy formulation in manufacturing is confirmed in answer to subquestion 5 .

E. Identifying the benefits of ecologically embedded strategy 
Table 7 Selected sustainable, green and/or circular manufactured products sold in the UK and their characteristics

\begin{tabular}{lllll}
\hline Buying & Product & Manufacturer & BOL
\end{tabular}

Behaviour

habitual Sugar (Silverspoon, $2 \mathrm{~kg}$ )

batteries (8 pack, AA)

Toilet cleaner (pine and mint $750 \mathrm{ml})$

Laundry liquid (1 litre)

Multi-purpose cleaner (spray, $700 \mathrm{ml}$ )

Washing up liquid (400 ml)

kitchen cleaner (zesty lemon $750 \mathrm{ml})$

$\begin{array}{rr}\text { AB Sugar- } & \text { Material input, production } \\ \text { British Sugar } & \text { process and by-product }\end{array}$

Duracell

Ecover

Bio-D

Delphis

Greenscents

Astonish production plant video 'How are batteries made?', EU town in Flanders, brass wire makes the nails, nickel plated steel cap, anode from zinc ingots, top secret performance enhancers, etc.

Certified B Corp, vegan friendly, no animal testing, etc., since 1979, own stateof-the-art factories in completely sustainable process

Concentrated, vegan cert etc., fragranced with essential oils, GM free, affordable, UK produced (Hull, East Yorkshire), ethically sourced ingredients, over 25 years, complete traceability on all ingredients

Certified B Corp and more, UK based and owned, all suppliers and business partners are UK based meaning lower env and human impact from transport, supply chain visibility (raw materialsextraction and processing)

rganic $(72 \%)$, sustainable packaging — all bottles are plastic-free made from biopolymer plastics from the waste products of sugar cane, certification by The Soil Association, etc. everything made in workshops in Dulverton, Somerset by small and experienced team

Certifications: cruelty free, vegan, etc., $2^{\text {nd }}$ generation family business in West Yorkshire, state-of-the-art purpose-built site, idea generation, lab,

manufacture, packaging all under one roof, distribution partner next door, incorporate two journeys into one when possible, local to reduce carbon footprint and build great relationships in the community

\section{Storage, preparation and usage, number of servings, nutritional info, 'sugar is a} natural preservative'

amount of charge remaining, product cascading, recycling responsible battery use and care

Fresh perfume from plantbased ingredients, safe to use, naturally powerful, no residue of unnecessary chemicals, exceptional cleaning

Low temperature and delicate fabrics, use tips, help consumers contribute to a healthier, more sustainable planet, free from colour and parabens

Tough on dirt, kind to the planet and health, totally free from harmful VOCs, animal safe and $100 \%$ vegan, cruelty free, plant based, pet safe

Kind to hands, number of uses, use instructions, healthy home, sustainable planet, no GM, no herbicides or synthetic fertilisers, free from harsh chemicals, nanoparticles, parabens, synthetic dyes and artificial fragrances, vegan

How to use, very toxic to aquatic organisms, may cause damage to organs (respiratory tract) through prolonged or repeated exposure... (safety data sheet)
Complete biodegradability, minimum impact on aquatic life, bottle and label are recyclable, 5 litre refills available

Bottle 100\% rHDPE, cap PP (100\% UK postconsumer waste bottle), can be recycled again, hundreds of independent stockists with increasing numbers offering refill stations

Packaging from recycled British plastic (100\%); bottle caps, spray triggers and labelling can be recycled, refills

Biopolymer packaging is recyclable, 201 jerrycan may be returned for washing and reuse, filler in boxes is from renewable sources, $100 \%$ biodegradable and fully compostable, packaging tape made from sustainable paper and $100 \%$ recyclable

Biodegradable, recyclable packaging 
Table 7 continued

\begin{tabular}{|c|c|c|c|c|c|}
\hline $\begin{array}{l}\text { Buying } \\
\text { Behaviour }\end{array}$ & Product & Manufacturer & BOL & MOL & EOL \\
\hline & Organic body wash $(200 \mathrm{ml})$ & Kinn Living & $\begin{array}{l}\text { Backstory and launch in } \\
2017 \text {, awards, made in } \\
\text { Britain, vegan friendly, } \\
\text { using family aromatherapy } \\
\text { recipes }\end{array}$ & $\begin{array}{l}\text { Vegan, not tested on animals, } \\
\text { plant based, natural- } \\
98.6 \% \text { on product pages, } \\
\text { organic } 73.2 \% \text {, certified } \\
\text { organic by Soil } \\
\text { Association COSMOS, } \\
\text { use advice, free from } \\
\text { parabens, colourants, etc. }\end{array}$ & $\begin{array}{l}\text { Not refillable but working on } \\
\text { it, packaging is recyclable }\end{array}$ \\
\hline & $\begin{array}{l}\text { Shampoo (lavender and geranium, } 5 \\
\text { litre) }\end{array}$ & Faith in Nature & $\begin{array}{l}\text { Founded } 1974 \text {, passionate } \\
\text { about keeping our prices } \\
\text { affordable and using only } \\
\text { the best natural } \\
\text { ingredients, manufacturing } \\
\text { locally, SEDEX } \\
\text { membership organisation, } \\
100 \% \text { natural fragrance }\end{array}$ & $\begin{array}{l}\text { Ingredient policy, no animal } \\
\text { testing etc., vegetarian and } \\
\text { vegan (registered with } \\
\text { Vegan Society), directions } \\
\text { for use }\end{array}$ & $\begin{array}{l}51 \text { refills, recycling locator } \\
\text { powered by recyclenow }\end{array}$ \\
\hline & mop (Deep Clean Mop) & e-cloth & $\begin{array}{l}\text { Recommended by Allergy } \\
\text { UK. Good Housekeeping } \\
\text { Institute approved. } \\
\text { Country of origin: China, } \\
\text { Taiwan }\end{array}$ & $\begin{array}{l}\text { Durable, lightweight } \\
\text { aluminium, special weave } \\
\text { breaks up and holds grease } \\
\text { and dirt ordinary mops } \\
\text { leave behind, cleans just } \\
\text { using water, no chemicals, } \\
\text { the power is in the fibres, } \\
\text { removes over } 99 \% \text { of } \\
\text { bacteria, } 3 \text { year guarantee, } \\
\text { use and care, machine } \\
\text { wash mop head regularly } \\
\text { up to } 60 \mathrm{C} \text { with a little } \\
\text { detergent }\end{array}$ & No \\
\hline & $\begin{array}{l}\text { Alkimi glass/window cleaner } \\
\qquad(500 \mathrm{ml})\end{array}$ & $\begin{array}{l}\text { Challs } \\
\text { International, } \\
\text { Ltd. }\end{array}$ & $\begin{array}{l}\text { Nature engineered, made } \\
\text { with natural ingredients } \\
\text { from sustainable sources }\end{array}$ & $\begin{array}{l}\text { Naturally fast acting, non- } \\
\text { toxic, safe, env. friendly } \\
\text { alternative to } \\
\text { petrochemical solvents, } \\
\text { without parabens, etc. }\end{array}$ & No \\
\hline & Toast Ale Craft Lager (beer in can) & Toast Ale & $\begin{array}{l}\text { Material input (surplus } \\
\text { bread), awards, certified B } \\
\text { corporation, buy social }\end{array}$ & No & Packaging only \\
\hline & Hardtack (beer in can) & Jaw Brew & $\begin{array}{l}\text { Material input (bread rolls), } \\
\text { production (traditional } \\
\text { methods, heat recovery), } \\
\text { by-product (cattle feed and } \\
\text { mulch), awards }\end{array}$ & No & $\begin{array}{l}\text { packaging (biodegradable } \\
\text { plastic connectors) }\end{array}$ \\
\hline & Thorough Bread (beer in bottle) & Bute Brew Co & $\begin{array}{l}\text { Material input (unsold } \\
\text { bread), production, awards }\end{array}$ & No & packaging only \\
\hline & $\begin{array}{l}\text { hot-rolled steel for automotive } \\
\text { industry }\end{array}$ & $\begin{array}{l}\text { TaTa Steel } \\
\text { (business } \\
\text { consumer) }\end{array}$ & $\begin{array}{l}\text { Material input, production } \\
\text { process and by-product }\end{array}$ & Customer processes benefits & Product and packaging \\
\hline
\end{tabular}


Table 7 continued

\begin{tabular}{|c|c|c|c|c|c|}
\hline $\begin{array}{l}\text { Buying } \\
\text { Behaviour }\end{array}$ & Product & Manufacturer & BOL & MOL & EOL \\
\hline \multirow[t]{3}{*}{$\begin{array}{l}\text { variety- } \\
\text { seeking }\end{array}$} & jeans & MUD Jeans & $\begin{array}{l}\text { Short supply chain with } \\
\text { lasting relationships, } \\
\text { recycling factory in } \\
\text { Valencia, organic cotton, } \\
\text { less water usage in } \\
\text { production than industry } \\
\text { standard, water output is } \\
\text { cleaner than input, carbon } \\
\text { neutral, renewable, fabrics } \\
\text { are up to } 40 \% \text { recycled } \\
\text { post-consumer denim, } \\
\text { energy in factories and use } \\
\text { recycled cotton, no toxic } \\
\text { chemicals in production, } \\
\text { Nordic Swan Ecolabel } \\
\text { certified and others, } \\
\text { innovation in processes, } \\
\text { e.g. laser instead of } \\
\text { sandpaper and chemical, } \\
\text { etc. }\end{array}$ & $\begin{array}{l}\text { Lease, vegan, zero impact, } \\
\text { better for your skin, wash } \\
\text { consciously }\end{array}$ & $\begin{array}{l}\text { Circular, take-back for jeans } \\
\text { that are more than } 96 \% \\
\text { cotton, recycle factory } \\
\text { Recovertex in Spain, } \\
\text { reusable packaging ( } 20 \\
\text { times), buttons and rivets } \\
\text { are stainless steel for } \\
\text { recycling, leather patch } \\
\text { replaced with printed label } \\
\text { for monomaterial } \\
\text { recycling }\end{array}$ \\
\hline & Shoes & Veja Shoes & $\begin{array}{l}\text { Material input - fair trade } \\
\text { and organic, no PVC in } \\
\text { supply chain, responsible } \\
\text { production on map, } \\
\text { certifications }\end{array}$ & $\begin{array}{l}\text { Hazardous chemical } \\
\text { elimination test }\end{array}$ & No \\
\hline & Mobile phone & Fairphone & $\begin{array}{l}\text { Material input, design, } \\
\text { supply chain, } \\
\text { manufacturing and life } \\
\text { cycle, awards }\end{array}$ & $\begin{array}{l}\text { Design for longevity, easy } \\
\text { repair and modular } \\
\text { upgrades }\end{array}$ & $\begin{array}{l}\text { Take-back program for } \\
\text { recycling }\end{array}$ \\
\hline \multirow[t]{5}{*}{$\begin{array}{l}\text { dissonance- } \\
\text { reducing }\end{array}$} & Washing machine (Eco 7 kg) & Miele & No & $\begin{array}{l}\text { Energy and water, built to } \\
\text { last }\end{array}$ & Provided by retailer \\
\hline & American fridge freezer (LSR100) & LG & No & $\begin{array}{l}\text { Instaview door in door for } \\
\text { less energy use, Smart } \\
\text { Diagnosis }\end{array}$ & No \\
\hline & $\begin{array}{l}\text { insulation }(6 \text { pack, } \\
1200 \mathrm{~mm} \times 400 \mathrm{~mm} \times 10 \mathrm{~mm})\end{array}$ & Rockwool & $\begin{array}{l}\text { Material input only-made } \\
\text { from naturally occurring } \\
\text { volcanic rock which is } \\
97 \% \text { recyclable }\end{array}$ & $\begin{array}{l}\text { Highly stable and durable- } \\
\text { works for the life time of } \\
\text { the building }\end{array}$ & $97 \%$ recyclable \\
\hline & $\begin{array}{l}\text { WorkForce Pro (WF-C8690DWF } \\
\text { SERIES) }\end{array}$ & $\begin{array}{l}\text { Epson (business } \\
\text { consumer) }\end{array}$ & No & Energy consumption & No \\
\hline & $\begin{array}{l}\text { coffee pod machine (SENSEO } \\
\text { Original) }\end{array}$ & Philips & material input packaging & $\begin{array}{l}\text { auto shutoff energy } \\
\text { consumption }\end{array}$ & No \\
\hline \multirow[t]{3}{*}{ complex } & Kitchen furniture (Kungsbacka) & IKEA & $\begin{array}{l}\text { Kitchen door made from } \\
\text { recycled materials (min. } \\
90 \% \text { recycled foil and } \\
\text { edging from PET bottles, } \\
\text { recycled wood), } \\
\text { production was developed } \\
\text { with supplier, PET bottles } \\
\text { collected in Japan, wood } \\
\text { from scrap, mills, } \\
\text { packaging }\end{array}$ & $\begin{array}{l}\text { Care instructions, impact } \\
\text { resistant, 25-year } \\
\text { guarantee }\end{array}$ & $\begin{array}{l}\text { Can be recycled repeatedly } \\
\text { but UK furniture } \\
\text { recycling/reuse is only for } \\
\text { bed, mattress, sofa and } \\
\text { appliances for a fee }\end{array}$ \\
\hline & hybrid car (Camry) & Toyota & No & $\begin{array}{l}\text { Fuel economy, emissions, } \\
\text { regenerative braking } \\
\text { hybrid brake pads last } \\
\text { longer than conventional, } \\
\text { hybrid service for } \\
\text { improved fuel economy }\end{array}$ & $\begin{array}{l}\text { Aim to recycle over } 50 \% \text { of } \\
\text { the weight of a hybrid } \\
\text { battery, recycling info } \\
\text { including marking plastic } \\
\text { for easier recycling, may } \\
\text { qualify for free take back } \\
\text { scheme or money back }\end{array}$ \\
\hline & Electric car (Leaf) & Nissan & No & energy usage, emissions & free recycling \\
\hline
\end{tabular}


Table 7 continued

\begin{tabular}{|c|c|c|c|c|c|}
\hline $\begin{array}{l}\text { Buying } \\
\text { Behaviour }\end{array}$ & Product & Manufacturer & BOL & MOL & EOL \\
\hline & $\begin{array}{l}\text { Landfill compactor (Cat } 816 \mathrm{~K}- \\
\text { one of Cat's most rebuilt } \\
\text { products) }\end{array}$ & $\begin{array}{l}\text { Finning } \\
\text { Caterpillar } \\
\text { (business } \\
\text { consumer) }\end{array}$ & $\begin{array}{l}\text { Built for multiple lives, } \\
\text { designed to last, } \\
\text { operations: energy } \\
\text { conservation, greenhouse } \\
\text { gas emissions reductions, } \\
\text { water conservation }\end{array}$ & $\begin{array}{l}\text { Emissions, info on biodiesel } \\
\text { fuel usage, engine idle } \\
\text { shutdown feature to save } \\
\text { fuel, service, lower } \\
\text { operating costs (Reman } \\
\text { products) }\end{array}$ & $\begin{array}{l}\text { Remanufacturing, rebuilding, } \\
\text { component reuse }\end{array}$ \\
\hline
\end{tabular}

Table 8 Truth Table for Ecological Embeddedness

\begin{tabular}{|c|c|c|c|c|c|c|}
\hline $\begin{array}{l}\text { Buying } \\
\text { behaviour }\end{array}$ & Product & Manufacturer & Provenance & Quality & Wholesome & Reclamation \\
\hline \multirow[t]{15}{*}{ Habitual } & Sugar (Silverspoon, $2 \mathrm{~kg}$ ) & AB Sugar-British Sugar & 1 & 0 & 1 & 0 \\
\hline & Batteries (8 pack, AA) & Duracell & 0 & 1 & 0 & 0 \\
\hline & Toilet cleaner (pine and mint $750 \mathrm{ml}$ ) & Ecover & 0 & 1 & 1 & 0 \\
\hline & Laundry liquid (1 litre) & Bio-D & 1 & 1 & 1 & 0 \\
\hline & Multi-purpose cleaner (spray, $700 \mathrm{ml}$ ) & Delphis & 1 & 1 & 1 & 0 \\
\hline & Washing up liquid (400 ml) & Greenscents & 1 & 1 & 1 & 0 \\
\hline & Kitchen cleaner (zesty lemon $750 \mathrm{ml}$ ) & Astonish & 1 & 0 & 0 & 0 \\
\hline & Organic body wash $(200 \mathrm{ml})$ & Kinn Living & 0 & 1 & 1 & 0 \\
\hline & Shampoo (lavender and geranium, 5 litre) & Faith in Nature & 0 & 0 & 1 & 0 \\
\hline & Mop (Deep Clean Mop) & e-cloth & 0 & 1 & 0 & 0 \\
\hline & Alkimi glass/window cleaner $(500 \mathrm{ml})$ & Challs International, Ltd. & 0 & 1 & 1 & 0 \\
\hline & Toast Ale Craft Lager (beer $330 \mathrm{ml}$ ) & Toast Ale & 0 & 0 & 0 & 0 \\
\hline & Hardtack (beer in can) & Jaw Brew & 1 & 0 & 0 & 0 \\
\hline & Thorough Bread (beer in bottle) & Bute Brew Co & 1 & 0 & 0 & 0 \\
\hline & hot-rolled steel for automotive industry & $\begin{array}{l}\text { TaTa Steel } \\
\text { (business consumer) }\end{array}$ & 1 & 0 & 0 & 0 \\
\hline \multirow[t]{3}{*}{ variety-seeking } & Jeans & MUD Jeans & 1 & 1 & 1 & 1 \\
\hline & Shoes & Veja Shoes & 1 & 1 & 1 & 0 \\
\hline & Mobile phone & Fairphone & 1 & 1 & 0 & 1 \\
\hline \multirow{5}{*}{$\begin{array}{l}\text { dissonance- } \\
\text { reducing }\end{array}$} & Washing machine (Eco $7 \mathrm{~kg}$ ) & Miele & 0 & 1 & 0 & 0 \\
\hline & American fridge freezer (LSR100) & LG & 0 & 1 & 0 & 0 \\
\hline & $\begin{array}{l}\text { Insulation }(6 \text { pack, } \\
\qquad 1200 \mathrm{~mm} \times 400 \mathrm{~mm} \times 10 \mathrm{~mm})\end{array}$ & Rockwool & 0 & 1 & 0 & 0 \\
\hline & $\begin{array}{l}\text { WorkForce Pro (WF-C8690DWF } \\
\text { SERIES) }\end{array}$ & Epson (business consumer) & 0 & 1 & 0 & 0 \\
\hline & Coffee pod machine (SENSEO Original) & Philips & 0 & 1 & 0 & 0 \\
\hline \multirow[t]{4}{*}{ complex } & Kitchen furniture (Kungsbacka) & IKEA & 0 & 1 & 0 & 0 \\
\hline & Hybrid car (Camry) & Toyota & 0 & 1 & 0 & 1 \\
\hline & Electric car (Leaf) & Nissan & 0 & 1 & 0 & 1 \\
\hline & Landfill compactor (Cat $816 \mathrm{~K}$ ) & $\begin{array}{l}\text { Finning Caterpillar (business } \\
\text { consumer) }\end{array}$ & 0 & 1 & 0 & 1 \\
\hline
\end{tabular}

Certain benefits of ecologically embedded manufacturing are evident in Table 9. Production tends towards minimal environmental impact, workers are treated responsibly, customers are engaged and materials are retained in a closed loop for manufacturers to utilise. Both MUD jeans and Fairphone evidence commercial success 
Table 9 Evidence for MUD Jeans and Fairphone

\begin{tabular}{|c|c|c|c|}
\hline & Predicted evidence & Actual evidence-MUD jeans & Actual evidence-Fairphone \\
\hline Understanding & $\begin{array}{l}\text { Vision/mission statements reflecting } \\
\text { maturity level, attitude and values } \\
\text { Ecological product qualities } \\
\text { Ecological production and value } \\
\text { chain characteristics }\end{array}$ & $\begin{array}{l}\text { Mission: '...producing it in the most } \\
\text { sustainable way...' } \\
\text { 'Our leaders are sustainability pioneers' } \\
\text { (Sustainability Report 2018) } \\
\text { Sustainable Development Goal (SDG) } \\
12 \text { is their favourite } \\
\text { Design for recycling } \\
\text { 'To actually take it back at the end of } \\
\text { life and recycle it is a completely } \\
\text { different story.' } \\
\text { Code of Conduct for employees, } \\
\text { suppliers and business partners }\end{array}$ & $\begin{array}{l}\text { Mission: 'We care for people and planet.' } \\
\text { 'Recycled and fair materials', 'modular and } \\
\text { repairable design' } \\
\text { Code of conduct: the Fairphone Ways of } \\
\text { Working Together (for supply chain), } \\
\text { contains...topics like the environment.... and } \\
\text { responsible sourcing }\end{array}$ \\
\hline Realising & $\begin{array}{l}\text { Ecological practices and innovations } \\
\text { in production } \\
\text { Ecological certifications } \\
\text { Ecological supply chain } \\
\text { characteristics }\end{array}$ & $\begin{array}{l}\text { Dye is organic and biodegradable } \\
\text { Two waste water treatment plants at } \\
\text { fabric mill } \\
\text { Use of laser and ozone to reduce water } \\
\text { consumption } \\
\text { Reverse osmosis so no fresh water is } \\
\text { used in production } \\
\text { Dry Indigo dyeing technique uses no } \\
\text { water and 90\% fewer chemicals } \\
\text { Energy self-sufficient with co- } \\
\text { generation station } \\
\text { Cutting waste is recycled } \\
\text { Packaging is reusable } \\
\text { Electric company cars } \\
\text { Certified B Corporation } \\
\text { Nordic Swan Ecolabel } \\
\text { PETA-approved vegan } \\
\text { Alliance for Responsible Denim (ARD) } \\
\text { Cradle to Cradle certified indigo dye } \\
\text { and paper labels } \\
\text { Ecocert for organic cotton } \\
\text { GRS (Global Recycle Standard) } \\
\text { transparency: } 3 \text { supply chain partners } \\
\text { only } \\
\text { Third-party audits of implementation of } \\
\text { Code of Conduct and supplier policies }\end{array}$ & $\begin{array}{l}\text { Responsible material sourcing } \\
\text { Increasing our use of recycled materials } \\
\text { Employee free in-house bike repairs, support } \\
\text { costs of public transport commute } \\
\text { Send modules to customers for in-warranty } \\
\text { repair instead of phone back and forth with } \\
95 \% \text { success rate } \\
\text { Fairtrade gold supply chain (Fairphone 2) as the } \\
\text { first Fairtrade-licensed consumer electronics } \\
\text { company } \\
\text { Nominated as partner for Responsible Business } \\
\text { Award } 2019 \\
\text { Blue Angel certification (Fairphone 2) } \\
\text { Mapping of first-tier assembly manufacturer, all } \\
\text { second-tier component suppliers, } \\
\text { progressively researching third and fourth-tier } \\
\text { suppliers and using this information to } \\
\text { engage...pioneer innovative solutions in our } \\
\text { impact areas, e.g. reducing hazardous } \\
\text { chemicals }\end{array}$ \\
\hline Utilising & $\begin{array}{l}\text { Evidence of communication of } \\
\text { ecological practices to consumers } \\
\text { through marketing, distribution } \\
\text { and/or retail }\end{array}$ & $\begin{array}{l}\text { Website (mudjeans.eu) } \\
\text { Sustainability Report } 2018 \\
\text { 'Timeless high-quality products } \\
\text { customers want': no sales or excess } \\
\text { stock, no pull model or seasons } \\
\text { Factory (production) tour for } \\
\text { consumers }\end{array}$ & Website (fairphone.com) \\
\hline Negotiating & $\begin{array}{l}\text { Evidence of consumers valuing, } \\
\text { accepting and trusting the } \\
\text { information provided } \\
\text { Evidence of consumer acquisition of } \\
\text { product }\end{array}$ & $\begin{array}{l}\text { Consumer interest in getting to know } \\
\text { 'everything about our jeans and us' } \\
\text { (Sustainability Report 2018) } \\
25,000 \text { jeans sold in } 2018 \text { (147\% } \\
\text { growth from 2016-2018) }\end{array}$ & $\begin{array}{l}\text { Phones recycled: } 198 \text { (14.10.2019), target } 2019 \text { : } \\
1600 \text { phones } \\
\text { More than } 125,000 \text { Fairphones sold to } 27 \\
\text { February } 2017 \text {, Fairphone } 2 \text { 'sold out' at } 22 \\
\text { March } 2019\end{array}$ \\
\hline
\end{tabular}


Table 9 continued

\begin{tabular}{|c|c|c|c|}
\hline & Predicted evidence & Actual evidence-MUD jeans & Actual evidence-Fairphone \\
\hline Reclaiming & $\begin{array}{l}\text { Evidence of product recovery by } \\
\text { manufacturer through consumer } \\
\text { involvement, engagement and } \\
\text { cooperation } \\
\text { Consumer engagement for feedback } \\
\text { Existence of a reverse supply chain } \\
\text { to the manufacturer }\end{array}$ & $\begin{array}{l}\text { Lease A Jeans system since } 2013 \text { with } \\
\text { free repairs } \\
\text { '...Interact through mail, livechat, } \\
\text { social media, blog, newsletter, events } \\
\text { and by as much as possible on our } \\
\text { website.' } \\
\text { Product return through the post }\end{array}$ & $\begin{array}{l}\text { 'Recycle your previous phone with us' 'Get } \\
\text { cash back on your Fairphone 3' } \\
\text { Support team (email), phone, community forum } \\
\text { Product return for money back through the post } \\
\text { with free shipping label generation } \\
\text { 'If you send us a phone that can be reused, the } \\
\text { revenue beyond costs, if any, goes to ...' }\end{array}$ \\
\hline
\end{tabular}

(growth in sales, 'sold out' of product). The manufacturer benefits all have wider societal benefits through reduced cumulative global planetary impacts, local economic stimulus, informed consumer response through greater awareness of ecological issues, and reduced global reliance on raw and critical materials. Hence, the answer to subquestion 6 is that not only are there benefits to ecologically embedded manufacturing, but that these benefits have broader implications for the sustainability of the planet and society.

\section{Discussion}

This research introduces ecological embeddedness as an ecocentric approach to manufacturing production and identifies causal paths to both ecological embeddedness and ecological disembeddedness. The main purpose of this research was to identify how the concept of ecological embeddedness could be extended from agricultural production to manufacturers in industry.

The overarching research question concerned strategy formulation in manufacturing with respect to ecological embeddedness was addressed through six subquestions. The literature review found that current definitions associated with sustainability, circularity and green products are complex and lack comprehensive or agreed characteristics and that ecologically embedded strategy remains unrealised with various concepts capturing only certain elements of ecocentric manufacturing. The literature review also determined that existing frameworks are inadequate for ecologically embedded manufacturing as there is a general omission of relational aspects. Consequently, a framework was proposed that addressed the missing functionality through holistic consideration of ecological relations at all lifecycle stages. In this way, subquestions 1-3 were addressed.

The purpose of subquestions 4-6 was justification and validation of the proposed framework. The two-stage process first identified the causal characteristics of ecologically embedded products, which were used to select appropriate cases for validation. The two selected cases were used to open up the 'black box' to establish viability of the proposed framework for strategy formulation (Beach 2016). These cases indicate a number of benefits to ecologically embedded manufacturing for both the individual manufacturer and globally from a systems perspective.

The proposed framework for ecologically embedded strategy formulation is fundamentally different from traditional and existing frameworks for sustainability strategies in that business strategy does not inform the manufacturing strategy (Skinner 1969; Ocampo and Ocampo 2015; Opresnik and Taisch 2015). Ecologically embedded strategy formulation is instead ecocentric with ecological operations informing the business strategy.

The framework for ecologically embedded strategy formulation is presented as an iterative process for continuous improvement which is confirmed by the two cases substantiating the mechanism. This indicates that manufacturers could utilise this framework to transform their practices in an iterative manner. Consumers play an important role in such a transformation. Although this research indicates that the framework is consistent with products reflecting variety-seeking buying behaviour, additional research is necessary before any limiting conclusions might be drawn.

Even in the elite category of green and sustainable products, followers have a lot to learn from leaders. For the products in the habitual buying behaviour category in which MOL and EOL considerations are largely irrelevant, packaging remains a concern and a differentiator. For dissonance-reducing and complex buying behaviour where MOL and EOL are a concern, cases indicate that compliance with legislation has driven manufacturer response with respect to consumer disclosure of resource consumption and recycling at EOL via third parties. Policymakers should reflect on actions that would encourage the formation of ecologically embedded relations between consumers and manufacturers. Similarly, manufacturers and investors may use this framework as an aid to futureproofing their decision-making due to the rising importance and benefits of being ecocentric. 


\section{Conclusion and Future Work}

This research has contributed to a greater understanding of ecological embeddedness in manufacturing. The application of ecocentric approaches to manufacturing is important to maintaining global biophysical ecosystems (Borland et al. 2016).

- Producers or manufacturers have two potential paths to ecologically embedded products: provenance or quality and wholesomeness.

- The feasibility of the framework for ecologically embedded strategy formulation for manufacturers (Fig. 1) has been demonstrated.

- Ecologically embedded manufacturing encompasses reclamation, i.e. the manufacturer and consumer taking responsibility for the product at end of life.

The results of stage 2 using PT are limited in that the framework is confirmed as a possible route to ecologically embeddedness, but it is not necessarily optimal or unique. Future work should focus on investigating the applicability of the framework to specific industries.

csQCA is a tool to enhance comparative knowledge about cases in small- and intermediate- $\mathrm{N}$ research designs. The dichotomisation of data is a limitation in general. For example, the cases revealed a diverse range of interpretations for circularity including packaging, process and product which become indistinguishable as only the product was considered in coding reclamation. The effect of such thresholds could be investigated in future work.

Another limitation is that QCA does not allow for analysis of temporal processes so that the conditions in the minimal formula are not chronologically specified. The minimal formulas with multiple terms developed in this research have not been dynamically interpreted. This may be a useful extension for manufacturers not able to pursue ecological embeddedness through provenance.

The major limitation of the framework is human decision-making. The decision-making by individuals in positions of power is prone to being limited in imagination, wedded to convention, ignorant, risk-averse, insensitive, clumsy, self-serving, and/or very easily affected by some form of socio-pathology. The framework does not mitigate these pitfalls. Similarly, the quality and quantity of information underlying the decision-making process will affect the outcome at each step of the framework. Consequently, implementation of the framework does not guarantee the intended outcome of ecological embeddedness will be achieved, but successive iterations may bring the manufacturer closer to that goal.

Future research could also attempt to replicate these findings in other countries with different economic, socio- cultural, and political settings. For instance, China is a leader in the top-down approach to circularity, whereas the EU and UK are adopting bottom-up approaches (Merli et al. 2018).

Acknowledgements The authors are grateful for proofreading by Keith Kaczmarek at the University of California, Santa Cruz (UCSC). This work has been presented at the 2nd Sustainable Solutions for Growth (SSG) conference held on 16-17 September 2019 in Wrocław (Poland).

\section{Compliance Ethical Standards}

Conflict of interest The authors declare that there is no conflict of interest.

Open Access This article is licensed under a Creative Commons Attribution 4.0 International License, which permits use, sharing, adaptation, distribution and reproduction in any medium or format, as long as you give appropriate credit to the original author(s) and the source, provide a link to the Creative Commons licence, and indicate if changes were made. The images or other third party material in this article are included in the article's Creative Commons licence, unless indicated otherwise in a credit line to the material. If material is not included in the article's Creative Commons licence and your intended use is not permitted by statutory regulation or exceeds the permitted use, you will need to obtain permission directly from the copyright holder. To view a copy of this licence, visit http://creativecommons.org/licenses/by/4.0/.

\section{References}

Adams, C., \& Frost, G. (2008). Integrating sustainability reporting into management practices. Accounting Forum, 32(4), 288-302.

Ageron, B., Gunasekaran, A., \& Spalanzani, A. (2012). Sustainable supply chain management: An empirical study. International Journal of Production Economics, 140(1), 168-182.

Allen, S., Cunliffe, A., \& Easterby-Smith, M. (2019). Understanding sustainability through the lens of ecocentric radical-reflexivity: Implications for management education. Journal of Business Ethics, 154(3), 781-795. https://doi.org/10.1007/s10551-0 16-3420-3.

Anbarasan, P., \& Sushil, (2018). Stakeholder Engagement in Sustainable Enterprise: Evolving a Conceptual Framework, and a Case Study of ITC. Business Strategy and the Environment, 27(3), 282-299.

Baas, L., \& Huisingh, D. (2008). The synergistic role of embeddedness and capabilities in industrial symbiosis: Illustration based upon 12 years of experiences in the Rotterdam Harbour and Industry Complex. Progress in Industrial Ecology: An International Journal, 5(5/6), 399-421.

Bae, H.-S., \& Grant, D. (2018). Investigating effects of organisational culture and learning on environmental collaboration and performance of Korean exporting firms. International Journal of Logistics Research and Applications, 21(6), 614-630.

Baritaux, V., Houdart, M., Boutonnet, J.-P., Chazoule, C., Corniaux, C., Fleury, P., et al. (2016). Ecological embeddedness in animal food systems (re-)localisation: A comparative analysis of initiatives in France, Morocco and Senegal. Journal of Rural Studies, 43, 13-26. https://doi.org/10.1016/j.jrurstud.201 5.11.009. 
Baumgartner, R., \& Ebner, D. (2010). Corporate sustainability strategies: Sustainability profiles and maturity levels. Sustainable Development, 18(2), 76-89. https://doi.org/10.1002/sd.447.

Beach, D. (2016). It's all about mechanisms-What process-tracing case studies should be tracing. New Political Economy, 21(5), 463-472. https://doi.org/10.1080/13563467.2015.1134466.

Beach, D., \& Pedersen, R. (2013). Process-tracing methods. Ann Arbor: University of Michigan Press.

Bennett, A. (2010). Process tracing and causal inference. In H. Brady \& D. Collier (Eds.), Rethinking social inquiry: Diverse tools, shared standards (2nd ed., pp. 207-219). Lanham, MD: Rowman and Littlefield.

Bennett, N., Whitty, T., Finkbeiner, E., Pittman, J., Bassett, H., Gelcich, S., et al. (2018). Environmental stewardship: A conceptual review and analytical framework. Environmental Management, 61(4), 597-614. https://doi.org/10.1007/ s00267-017-0993-2.

Berg-Schlosser, D., \& De Meur, G. (2009). Comparative research design case and variable selection. In B. Rihoux \& C. Ragin (Eds.), Configurational comparative methods qualitative comparative analysis (QCA) and related techniques (pp. 1-32). Thousand Oaks, USA: SAGE Publications Inc.

Biloslavo, R., Bagnoli, C., \& Edgar, D. (2018). An eco-critical perspective on business models: The value triangle as an approach to closing the sustainability gap. Journal of Cleaner Production, 174, 746-762.

Bocken, N., De Pauw, I., Bakker, C., \& van der Grinten, B. (2016). Product design and business model strategies for a circular economy. Journal of Industrial and Production Engineering, 33(5), 308-320. https://doi.org/10.1080/21681015.2016.1172124.

Bonn, I., \& Fisher, J. (2011). Sustainability: The missing ingredient in strategy. Journal of Business Strategy, 32(1), 5-14.

Borland, H., Ambrosini, V., Lindgreen, A., \& Vanhamme, J. (2016). Building theory at the intersection of ecological sustainability and strategic management. Journal of Business Ethics, 135(2), 293-307.

Borland, H., Bhatti, Y., \& Lindgreen, A. (2019). Sustainability and sustainable development strategies in the UK plastic electronics industry. Corporate Social Responsibility and Environmental Management, 26(4), 1-14. https://doi.org/10.1002/csr.1722.

Braun, V., \& Clarke, V. (2006). Using thematic analysis in psychology. Qualitative Research in Psychology, 3(2), 77-101. https://doi.org/10.1191/1478088706qp063oa.

British Standards. (2017). BS 8001: 2017 Circular Economy. British Standards. https://www.bsigroup.com/en-GB/standards/benefitsof-using-standards/becoming-more-sustainable-with-standards/ BS8001-Circular-Economy/.

Carson, R., Hamel, Z., Giarrocco, K. B., \& Mathews, L. (2016). Buying in the influence of interactions at farmers' markets. Agriculture and Human Values, 33(4), 861-875. https://doi.org/ 10.1007/s10460-015-9675-y.

Casadesus-Masanell, R., \& Ricart, J. (2010). From strategy to business models and onto tactics. Long Range Planning, 43(2-3), 195-215. https://doi.org/10.1016/j.lrp.2010.01.004.

Charmaz, K. (2006). Constructing grounded theory. London: Sage.

Charnwood. (2019). Farmers' market. Retrieved from Charnwood AZ of Services: https://www.charnwood.gov.uk/pages/farmers_m arket

Collier, D. (2011). Understanding process tracing. Political Science and Politics, 44(4), 823-830.

Cronqvist, L. (n.d.). Tosmana-Tool for $c s-, m v$-, and $f_{s} Q C A$ Version 1.6.1.0. Tosmana. University of Trier. www.tosmana.net

Corsini, F., Rizzi, F., Gusmerotti, N., \& Frey, M. (2015). Extended producer responsibility and the evolution of sustainable specializations: Evidences from the e-waste sector. Business Strategy and the Environment, 24(6), 466-476. https://doi.org/10.1002/bs e.1831.

Danciu, V. (2013). The sustainable company: New challenges and strategies for more sustainability. Theoretical and Applied Economics, 18(9), 7-26.

Dangelico, R., \& Vocalelli, D. (2017). "Green Marketing": An analysis of definitions, strategy steps, and tools through a systematic review of the literature. Journal of Cleaner Production, 165, 1263-1279. https://doi.org/10.1016/j.jclepro.2017.07.184.

de Brucker, K., Macharis, C., \& Verbeke, A. (2013). Multi-criteria analysis and the resolution of sustainable development dilemmas: A stakeholder management approach. European Journal of Operational Research, 224(1), 122-131.

De Young, R. (1986). Some psychological aspects of recycling: The structure of conservation satisfactions. Environment and Behaviour, 18(4), 435-449.

Dey, S., Sharma, R., \& Pandey, B. (2019). Relationship of manufacturing flexibility with organizational strategy. Global Journal of Flexible Systems Management, 20, 237-256. https://doi.org/10. 1007/s40171-019-00212-x.

DiMaggio, P., \& Powell, W. (1983). The iron cage revisited: Institutional isomorphism and collective rationality in organizational fields. American Sociological Review, 48(2), 147-160.

Elias, A. A. (2019). Strategy Development Through Stakeholder Involvement: A New Zealand Study. Global Journal of Flexible Systems Management, 20(4), 313-322.

Elkington, J. (1997). Cannibals with forks: The triple bottom line of 21st century business. Oxford: Capstone.

Elkington, J. (1998). Accounting for the triple bottom line. Measuring Business Excellence, 2(3), 18-22.

Ellen MacArthur Foundation. (2015). Delivering the circular economy. A Toolkit for Policymakers. https://www.ellenmacarthurfou ndation.org/assets/downloads/publications/ EllenMacArthurFoundation_PolicymakerToolkit.pdf

Engert, S., Rauter, R., \& Baumgartner, R. (2016). Exploring the integration of corporate sustainability into strategic management: A literature review. Journal of Cleaner Production, 112(4), 2833-2850. https://doi.org/10.1016/j.jclepro.2015.08.0 31.

Euchi, J., Bouzidi, D., \& Bouzid, Z. (2019). Interpretive structural modeling technique to analyze the interactions between the factors influencing the performance of the reverse logistics chain. Global Journal of Flexible Systems Management, 20(1), $43-55$.

Fehrenback, K., \& Wharton, C. (2012). Consumer informationseeking preferences at a university farmers' market. Journal of Hunger and Environmental Nutrition, 7(1), 53-63.

Figueroa-Rodríguez, K., del Carmen Álvarez-Ávila, M., Castillo, F., Rindermann, R., \& Figueroa-Sandoval, B. (2019). Farmers' market actors, dynamics, and attributes: A bibliometric study. Sustainability, 11(3), 745. https://doi.org/10.3390/su11030745.

Fine, C., \& Hax, A. (1985). Manufacturing strategy: A methodology and an illustration. Interfaces, 15(6), 28-46.

Florida, R. (1996). Lean and green: The move to environmentally conscious manufacturing. California Management Review, 39(1), 80-105.

Garetti, M., \& Taisch, M. (2011). Sustainable manufacturing: trends and research challenges. Production Planning \& Control, 23(2-3), 83-104.

Garner, B. (2018). Sustainability marketing at the farmers' market: An ethnographic analysis of ambiguous communication. International Journal of Consumer Studies, 43(1), 1. https://doi.org/10.1111/ijcs.12479.

Gatersleben, B., Murtagh, N., Cherry, M., \& Watkins, M. (2019). Moral, wasteful, frugal, or thrifty? identifying consumer identities to understand and manage pro-environmental behavior. 
Environment and Behaviour, 51(1), 24-49. https://doi.org/10.1 177/0013916517733782.

Geissdoerfer, M., Savaget, P., Bocken, N., \& Hultink, E. (2017). The circular economy-A new sustainability paradigm? Journal of Cleaner Production, 143, 757-768. https://doi.org/10.1016/j.jcl epro.2016.12.048.

Ghisellini, P., Cialani, C., \& Ulgiati, S. (2016). A review on circular economy: the expected transition to a balanced interplay of environmental and economic systems. Journal of Cleaner Production, 114, 11-32. https://doi.org/10.1016/j.jclepro.2015.0 9.007.

Gimenez, C., Sierra, V., \& Rodon, J. (2012). Sustainable operations: Their impact on the triple bottom line. International Journal of Production Economics, 140(1), 149-159.

Gond, J.-P., Grubnic, S., Herzig, C., \& Moon, J. (2012). Configuring management control systems: Theorizing the integration of strategy and sustainability. Management Accounting Research, 23(3), 205-223. https://doi.org/10.1016/j.mar.2012.06.003.

Grainger-Brown, J., \& Malekpour, S. (2019). Implementing the sustainable development goals: A review of strategic tools and frameworks available to organizations. Sustainability, 11(5), 1381.

Gray, J., Whyte, I., \& Curry, P. (2018). Ecocentrism: What it means and what it implies. The Ecological Citizen, 1, 130-131.

Günther, K. (2016). Key factors for successful implementation of a sustainability strategy. Journal of Applied Leadership and Management, 4, 1-20.

Gupta, A., \& Gupta, N. (2019). Innovation and culture as a dynamic capability for firm performance: A study from emerging markets. Global Journal of Flexible Systems Management, 20, 323-336. https://doi.org/10.1007/s40171-019-00218-5.

Gusmerotti, N., Testa, F., Corsini, F., Pretner, G., \& Iraldo, F. (2019). Drivers and approaches to the circular economy in manufacturing firms. Journal of Cleaner Production, 230, 314-327. https://doi.org/10.1016/j.jclepro.2019.05.044.

Hart, S. (1995). A natural-resource-based view of the firm. Academy of Management Review, 20(4), 986-1014.

Hassan, M., Nordin, N., \& Ashari, H. (2016). Environmental stewardship issue among Malaysian manufacturing firms. International Journal of Supply Chain Management, 5(2), 36-42.

Hinchcliffe, S., Blowers, A., \& Freeland, J. (2003). Understanding environmental issues. Milton Keynes: Wiley.

Hopkinson, P., Zils, M., Hawkins, P., \& Roper, S. (2018). Managing a complex global circular economy business model: Opportunities and challenges. California Management Review, 60(3), 71-94. https://doi.org/10.1177/0008125618764692.

Hughner, R., McDonagh, P., Prothero, A., Schultz, C., \& Stanton, J. (2007). Who are organic food consumers? A compilation and review of why people purchase organic food. Journal of Consumer Behaviour, 6(2-3), 94-110. https://doi.org/10.1002/c b. 210 .

Ilbery, B., \& Kneafsey, M. (2000). Producer constructions of quality in regional speciality food production: A case study from south west England. Journal of Rural Studies, 16(2), 217-230.

Imran, S., Alam, K., \& Beaumont, N. (2014). Reinterpreting the definition of sustainable development for a more ecocentric reorientation. Sustainable Development, 22(2), 134-144. https://doi.org/10.1002/sd.537.

Jain, S., \& Kibira, D. (2010). A framework for multi-resolution modeling of sustainable manufacturing. In Proceedings of the Winter Simulation Conference (pp. 3423-3434). Baltimore, MD: IEEE.

Jordan, E., Gross, M., Javernick-Will, A. N., \& Garvin, M. (2011). Use and misuse of qualitative comparative analysis. Construction Management and Economics, 29(11), 1159-1173. https://doi.org/10.1080/01446193.2011.640339.
Kashmanian, R., Wells, R., \& Keenan, C. (2011). Corporate environmental sustainability strategy: Key elements. Journal of Corporate Citizenship, 44, 107-130.

Kemper, J., \& Ballantine, P. (2019). What do we mean by sustainability marketing? Journal of Marketing Management, 35(3-4), 277-309. https://doi.org/10.1080/0267257X.2019.1573 845.

Khanmohammadi, E., Zandieh, M., \& Tayebi, T. (2019). Drawing a strategy canvas using the fuzzy best-worst method. Global Journal of Flexible Systems Management, 20, 57-75. https://doi.org/10.1007/s40171-018-0202-z.

Kirwan, J. (2004). Alternative strategies in the UK agro-food system: Interrogating the Alterity of farmers' markets. Sociologia Ruralis, 44(4), 395-415.

Kirwan, J., Maye, D., \& Brunori, G. (2017). Acknowledging complexity in food supply chains when assessing their performance and sustainability. Journal of Rural Studies, 52, 21-32. https://doi.org/10.1016/j.jrurstud.2017.03.008.

Klimek, M., Bingen, J., \& Freyer, B. (2018). Metropolitan farmers markets in Minneapolis and Vienna: A values-based comparison. Agriculture and Human Values, 35(1), 83-97.

Koistinen, K. (2019). Actors in Sustainability Transitions. Lappeenranta, Finland: Lappeenranta-Lahti University of Technology LUT. http://urn.fi/URN:ISBN:978-952-335-349-7

Kotler, P. (2002). Marketing management, millennium edition custom edition for University of Phoenix. USA: Pearson Custom Publishing.

Kotler, P., \& Armstrong, G. (2010). Principles of marketing. Pennsylvania State University: Prentice Hall.

Kraaijenbrink, J., Spender, J., \& Groen, A. (2010). The resourcebased view: A review and assessment of its critiques. Journal of Management, 36(1), 349-372.

Kumar, V., Rahman, Z., \& Kazmi, A. (2013). Sustainability marketing strategy: An analysis of recent literature. Global Business Review, 14(4), 601-625. https://doi.org/10.1177/09721 50913501598 .

Kunamaneni, S., Jassi, S., \& Hoang, D. (2019). Promoting reuse behaviour: Challenges and strategies for repeat purchase, lowinvolvement products. Sustainable Production and Consumption, 20, 253-272. https://doi.org/10.1016/j.spc.2019.07.001.

Landrum, N., \& Ohsowski, B. (2018). Identifying worldviews on corporate sustainability: A content analysis of corporate sustainability reports. Business Strategy and the Environment, 27(1), $128-151$.

Malaviya, P., \& Wadhwa, S. (2005). Innovation management in organizational context: an empirical study. Global Journal of Flexible Systems Management, 6(2), 1-14.

Le Roux, C., \& Pretorius, M. (2016). Navigating sustainability embeddedness in management decision-making. Sustainability, 8(5), 444. https://doi.org/10.3390/su8050444.

Lemke, F., \& Luzio, J. (2014). Exploring green consumers' mind-set toward green product design and life cycle assessment: The case of skeptical Brazilian and Portuguese green consumers. Journal of Industrial Ecology, 18(5), 619-630.

Leonidou, L., Leonidou, C., \& Kvasova, O. (2010). Antecedents and outcomes of consumer environmentally friendly attitudes and behaviour. Journal of Marketing Management, 26(13-14), 1319-1344.

Lieder, M., \& Rashid, A. (2016). Towards circular economy implementation: A comprehensive review in context of manufacturing industry. Journal of Cleaner Production, 115, 36-51.

Luchs, M., \& Swan, K. (2011). Perspective: The emergence of product design as a field of marketing inquiry. Journal of Product Innovation Management, 28(3), 327-345. https://doi.org/10.1111/j.1540-5885.2011.00801.x. 
Lüdeke-Freund, F., Gold, S., \& Bocken, N. (2018). A review and typology of circular economy business model patterns. Journal of Industrial Ecology, 23(1), 36-61. https://doi.org/10.1111/jiec. 12763.

Luxmore, S., Hull, C., \& Tang, Z. (2018). Institutional determinants of environmental corporate social responsibility: Are multinational entities taking advantage of weak environmental enforcement in lower-income nations? Business and Society Review, 123(1), 1. https://doi.org/10.1111/basr.12138.

Luzio, J., \& Lemke, F. (2013). Exploring green consumers' product demands and consumption processes: The case of Portuguese green consumers. European Business Review, 25(3), 281-300. https://doi.org/10.1108/09555341311314825.

Manninen, K., Koskela, S., Antikainen, R., \& Dahlbo, H. (2017). Do business models capture the circular economy value propositions? Journal of Cleaner Production, 171, 413-422. https://doi.org/10.1016/j.jclepro.2017.10.003.

Mathevet, R., Bousquet, F., Larrère, C., \& Larrère, R. (2018). Environmental stewardship and ecological solidarity: Rethinking social-ecological interdependency and responsibility. Journal of Agricultural and Environmental Ethics, 31(5), 605-623.

Matos, S., \& Silvestre, B. S. (2013). Managing stakeholder relations when developing sustainable business models: The case of the Brazilian energy sector. Journal of Cleaner Production, 45, 61-73.

McGrath, R. (2013). The end of competitive advantage. Boston, MA: Harvard Business Review Press.

Melnik, A., Ermolaev, K., \& Kuzmin, M. (2019). Mechanism for adjustment of the companies innovative activity control indicators to their strategic development goals. Global Journal of Flexible Systems Management, 20, 189-218. https://doi.org/10. 1007/s40171-019-00210-z.

Merli, R., Preziosi, M., \& Acampora, A. (2018). How do scholars approach the circular economy? A systematic literature review. Journal of Cleaner Production, 178, 730. https://doi.org/10.101 6/j.jclepro.2017.12.112.

Michaelidou, N., \& Dibb, S. (2009). Brand switching in clothing: the role of variety-seeking drive and product category-level characteristics. International Journal of Consumer Studies, 33(3), 322-326. https://doi.org/10.1111/j.1470-6431.2009.00764.x.

Migliore, G., Schifani, G., \& Cembalo, L. (2015). Opening the black box of food quality in the short supply chain: Effects of conventions of quality on consumer choice. Food Quality and Preference, 39, 141-146. https://doi.org/10.1016/j.foodqual.20 14.07.006.

Morabito, J., Sack, I., Stohr, E., \& Bhate, A. (2009). Designing flexible organizations. Global Journal of Flexible Systems Management, 10, 1-10. https://doi.org/10.1007/BF03396557.

Morris, C., \& Kirwan, J. (2011). Ecological embeddedness: An interrogation and refinement of the concept within the context of alternative food networks in the UK. Journal of Rural Studies, 27(3), 322-330.

Munthu, M.-C. (2009). The buying decision process and types of buying decision behaviour. Sibiu Alma Mater University Journals Series A Economic Sciences, 2(4), 27-33.

Murray, A., Skene, K., \& Haynes, K. (2017). The circular economy: An interdisciplinary exploration of the concept and application in a global context. Journal of Business Ethics, 140, 369-380. https://doi.org/10.1007/s10551-015-2693-2.

Nußholz, J. (2017). Circular business models: Defining a concept and framing an emerging research field. Sustainability, 9(10), 1810. https://doi.org/10.3390/su9101810.

Ocampo, L., \& Ocampo, C. (2015). A proposed sustainable manufacturing strategy framework. Business Systems and Economics, 5(1), 87-98. https://doi.org/10.13165/VSE-15-5-1-08.
Okada, E., \& Mais, E. (2010). Framing the "Green" alternative for environmentally conscious consumers. Sustainability Accounting, Management and Policy Journal, 1(2), 222-234.

Opresnik, D., \& Taisch, M. (2015). The Conceptualization of Sustainability in Operations Management. In The 22nd CIRP conference on Life Cycle Engineering (pp. 532-537). Elsevier B.V.

Penker, M. (2006). Mapping and measuring the ecological embeddedness of food supply chains. Geoforum, 37(3), 368-379. https://doi.org/10.1016/j.geoforum.2005.09.001.

Petersen, J., Frantz, C., Tincknell, E., \& Canning, C. (2018). An animated visual representation of real-time resource flows through a community enhances systems thinking. Systems Research and Behavioural Science, 35(6), 718-737. https://doi.org/10.1002/sres.2514.

Placet, M., Anderson, R., \& Fowler, K. (2005). Strategies for sustainability. Research Technology Management, 48(5), 32-41.

Polanyi, K. (1944). The great transformation: The political and economic origins of our time. New York: Farrar \& Rinehart.

Potrich, L., Cortimiglia, M., \& de Medeiros, J. (2019). A systematic literature review on firm-level proactive environmental management. Journal of Environmental Management, 243, 273-286. https://doi.org/10.1016/j.jenvman.2019.04.110.

Poveda, A., \& Martínez, C. (2013). Qualitative comparative analysis (QCA): An application for the industry. Quality \& Quantity, 47(3), 1315-1321. https://doi.org/10.1007/s11135-011-9592-0.

Prieto-Sandoval, V., Ormazabal, M., Jaca, C., \& Viles, E. (2018). Key elements in assessing circular economy implementation in small and medium-sized enterprises. Business Strategy and the Environment, 27(8), 1525-1534. https://doi.org/10.1002/bse.2210.

Ragin, C. (2006). Set Relations in social research: Evaluating their consistency and coverage. Political Analysis, 14(3), 291-310. https://doi.org/10.1093/pan/mpj019.

Rashid, A., Asif, F., Krajnik, P., \& Nicolescu, C. (2013). Resource conservative manufacturing: An essential change in business and technology paradigm for sustainable manufacturing. Journal of Cleaner Production, 57(15), 166-177.

Rihoux, B., \& De Meur, G. (2009). Crisp-set qualitative comparative analysis (csQCA). In B. Rihoux \& C. Ragin (Eds.), Configurational Comparative Methods (pp. 33-68). USA: Sage.

Roper, S., Hopkinson, P., Zils, M., \& Hawkins, P. (2017). Managing a complex global circular economy business model: Opportunities and challenges. California Management Review, 60(3), 71-94.

Saari, U., Fritz, M., Mäkinen, S., \& Baumgartner, R. (2018). Designing green marketing across industries: A conceptual framework and implications for consumers and transdisciplinary research. In W. Leal Filho (Ed.), Handbook of Sustainability Science and Research (pp. 581-596). Cham: Springer.

Sarka, D., \& Bouvrain, S. (2015). Compatibility of corporate sustainability with a cost leadership strategy. Linköping: Linköping University.

Sarkis, J. (2001). Manufacturing's role in corporate environmental sustainability: Concerns for the new millennium. International Journal of Operations and Production Management, 21(5/6), 666-686.

Satyro, W., Sacomano, J., Contador, J., Almeida, C., \& Giannetti, B. (2017). Process of strategy formulation for sustainable environmental development: Basic model. Journal of Cleaner Production, 166, 1295-1304.

Saylor, R. (2018). Why causal mechanisms and process tracing should alter case selection guidance. Sociological Methods \& Research. https://doi.org/10.1177/0049124118769109.

Schifani, G., Romeo, P., Dara Guccione, G., Schimmenti, E., Columba, P., \& Migliore, G. (2016). Conventions of quality in consumer preference toward local honey in southern Italy. Quality-Access to Success, 17(153), 92-97. 
Schjøll, A. (2017). Country-of-origin preferences for organic food. Organic Agriculture, 7(3), 315-327.

Scott, K. (2019, April 8). Average advertised UK salary rises to $£ 35,058$ per year. Retrieved from employee benefits: https://www.employeebenefits.co.uk/advertised-salaries-uk$35058 /$.

Seuring, S., \& Müller, M. (2008). From a literature review to a conceptual framework for sustainable supply chain management. Journal of Cleaner Production, 16(15), 1699-1710.

Sevanandee, B., \& Damar-Ladkoo, A. (2018). Country-of-origin effects on consumer buying behaviours: A case of mobile phones. Studies in Business and Economics, 13(2), 179-201. https://doi.org/10.2478/sbe-2018-0029.

Sharma, M. (2014). The impact on consumer buying behaviour: Cognitive dissonance. Global Journal of Finance and Management, 6(9), 833-840.

Sharma, N., Saha, R., \& Rameshwar, R. (2019). "I don't buy LED bulbs but I switch off the lights": Green consumption versus sustainable consumption. Journal of Indian Business Research, 11(2), 138-161.

Shrivastava, P. (1995). Environmental technologies and competitive advantage. Strategic Management Journal, 16(S1), 183-200. https://doi.org/10.1002/smj.4250160923.

Shukla, S., Sushil, \& Sharma, M. (2019). Managerial paradox toward flexibility: Emergent views using thematic analysis of literature. Global Journal of Flexible Systems Management, 20, 349-370. https://doi.org/10.1007/s40171-019-00220-x.

Skinner, W. (1969). Manufacturing-Missing link in corporate strategy. Harvard Business Review, 47(3), 136-145.

Solomon, M. (2004). Consumer behavior: Buying, having, and being (6th ed.). Upper Saddle River: Pearson/Prentice Hall.

Stewart, R., \& Niero, M. (2018). Circular economy in corporate sustainability strategies: A review of corporate sustainability reports in the fast-moving consumer goods sector. Business Strategy and the Environment, 27(7), 1005-1022. https://doi.org/ 10.1002/bse.2048.

Sushil, (2015). Valuation of flexibility. Global Journal of Flexible Systems Management, 16, 219-220.

Svenfelt, A., \& Carlsson-Kanyama, A. (2010). Farmers' marketsLinking food consumption and the ecology of food production? Local Environment, 15(5), 453-465.

Teece, D., Pisano, G., \& Shuen, A. (1997). Dynamic capabilities and strategic management. Strategic Management Journal, 18(7), $509-533$

Thomas, N. (2018). Sustainability marketing: The need for a realistic whole systems approach. Journal of Marketing Management, 34(17-18), 1530-1556. https://doi.org/10.1080/0267257x.2018. 1547782.

Tsai, M., Chuang, L.-M., Chao, S.-T., \& Chang, H.-P. (2012). The effects assessment of firm environmental strategy and customer environmental conscious on green product development. Environmental Monitoring and Assessment, 184(7), 4435-4447.

Ünal, E., \& Shao, J. (2019). A taxonomy of circular economy implementation strategies for manufacturing firms: Analysis of 391 cradle-to-cradle products. Journal of Cleaner Production, 212, 754-765. https://doi.org/10.1016/j.jclepro.2018.11.291.

Ungerman, O., \& Dědková, J. (2019). Model of the circular economy and its application in business practice. Environment, Development and Sustainability, 22, 3407-3432. https://doi.org/10.1007/ s10668-019-00351-2.

Urbinati, A., Chiaroni, D., \& Chiesa, V. (2017). Towards a new taxonomy of circular economy business models. Journal of
Cleaner Production, 168, 487-498. https://doi.org/10.1016/j.jc lepro.2017.09.047.

Van Evera, S. (1997). Guide to methods for students of political science. Ithaca, NY: Cornell University Press.

Venkatraman, N. (1989). The concept of fit in strategy research: Toward verbal and statistical correspondence. The Academy of Management Review, 14(3), 423-444. https://doi.org/10.23 07/258177.

Waage, S., Geiser, K., Irwin, F., Weissman, A., Bertolucci, M., Fisk, P., et al. (2005). Fitting together the building blocks for sustainability: A revised model for integrating ecological, social, and financial factors into business decision-making. Journal of Cleaner Production, 13(12), 1145-1163.

Wägeli, S., \& Hamm, U. (2016). Consumers' perception and expectations of local organic food supply chains. Organic Agriculture, 6(3), 215-224.

Walker, K., Ni, N., \& Dyck, B. (2013). Recipes for successful sustainability: Empirical organizational configurations for strong corporate environmental performance. Business Strategy and the Environment, 24(1), 40-57. https://doi.org/10.1002/bse.1805.

Walley, K., Custance, P., \& Parsons, S. (2000). UK consumer attitudes concerning environmental issues impacting the agrifood industry. Business Strategy and the Environment, 9(6), 355-366. https://doi.org/10.1002/1099-0836(200011/12)9:6\%3c355:AIDBSE263\%3e3.0.CO;2-H.

Whiteman, G., \& Cooper, W. (2000). Ecological embeddedness. Academy of Management Journal, 43(6), 1265-1282.

Whiteman, G., \& Cooper, W. (2011). Ecological sensemaking. Academy of Management Journal, 54(5), 889-911.

Wójcik, P. (2015). Exploring links between dynamic capabilities perspective and resource-based view: A literature overview. International Journal of Management and Economics, 45(1), 83-107. https://doi.org/10.1515/ijme-2015-0017.

Wood, G., Day, R., Creamer, E., van der Horst, D., Hussain, A., Liu, S., et al. (2019). Sensors, sense-making and sensitivities: UK household experiences with a feedback display on energy consumption and indoor environmental conditions. Energy Research \& Social Science, 55, 93-105. https://doi.org/10.10 16/j.erss.2019.04.013.

Yuan, C., Zhai, Q., \& Dornfeld, D. (2012). A three dimensional system approach for environmentally sustainable manufacturing. CIRP Annals-Manufacturing Technology, 61(1), 39-42.

Zahraee, S. M., Mamizadeh, F., \& Vafaei, S. A. (2018). Greening assessment of suppliers in automotive supply chain: An empirical survey of the automotive industry in Iran. Global Journal of Flexible Systems Management, 19(3), 225-238.

Publisher's Note Springer Nature remains neutral with regard to jurisdictional claims in published maps and institutional affiliations.

\section{Key Questions}

1. What strategic flexibility is required of management for ecological embeddedness?

2. What are the barriers to ecologically embedded strategy formulation?

3. How could you implement the transformation change framework in your organisation? 


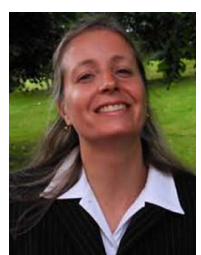

H. Trollman is a $\mathrm{PhD}$ Research Student at the Wolfson School of Mechanical, Electrical and Manufacturing Engineering at Loughborough University. Hana has been involved in a number of research projects including the EPSRC Centre for Innovative Manufacturing in Industrial Sustainability, EPSRC Centre for Innovative Manufacturing in Food, and H2020 Activating Circular Services in the Electric and Electronic Sector (C-SERVEES). Hana's research interests include sustainable manufacturing and circular economy in the context of systems thinking. Specifically, Hana's $\mathrm{PhD}$ focuses on strategy for the ecological embeddedness of manufacturing.

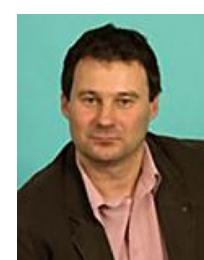

J. A. Colwill is a Lecturer in Sustainable Design and Manufacturing at the Wolfson School of Mechanical, Electrical and Manufacturing Engineering at Loughborough University. James has spent 20 years in industry working primarily as a consultant in technology-based design and innovation across a wide range of manufacturing sectors. He has broad industrial experience of enterprise, including establishing and running international start-up companies. His research interests include life cycle assessment and environmental management systems, resource efficient manufacturing, and management and strategy for renewable resources. 